\title{
The magic of the magic lantern (1660-1700): on analogical demonstration and the visualization of the invisible
}

\author{
KOEN VERMEIR*
}

\begin{abstract}
The history of the magic lantern provides a privileged case study with which to explore the histories of projection, demonstration, illusion and the occult, and their different intersections. I focus on the role of the magic lantern in the work of the Jesuit Athanasius Kircher and the French Cartesian Abbé de Vallemont. After explaining the various meanings of the seventeenth-century concept of illusio, I propose a new solution for the long-standing problem that Kircher added the 'wrong' illustrations to his description of the lantern. The complex interaction between text, image and performance was crucial in Kircher's work and these 'wrong' figures provide us with a key to interpreting his Ars Magna. I argue that Vallemont used the magic lantern in a similar rhetorical way in a crucial phase of his argument. The magic lantern should not be understood merely as an illustrative image or an item of demonstration apparatus; rather the instrument is employed as part of a performance which is not meant simply to be entertaining. Both authors used a special form of scientific demonstration, which I will term 'analogical demonstration', to bolster their world view. This account opens new ways to think about the relation between instruments and the occult.
\end{abstract}

Sol fons lucis universi, vas admirabile, opus Excelsi, divinitatis thalamus, risus coeli, decor, \& pulchritudo mundi

A. Kircher

For one of those Gnostics, the visible universe was an illusion or, more precisely, a sophism. Mirrors and fatherhood are abominable because they multiply it and extend it.

J. L. Borges

I have chosen a special instrument through which to enter the scene of seventeenthcentury science. The magic lantern (Figure 1), a projection device throwing luminous shadows on a screen, provides an intersection where different cultural spheres

* Institute of Philosophy, University of Leuven, Kard. Mercierplein 2, B-3000 Leuven, Belgium.

Many thanks to Nick Dew, Frank Scheppers, Jutta Schickore, Liba Taub and Nick Wilding for their encouraging comments, and especially to Lauren Kassell for her support and to Simon Schaffer for his imaginative remarks. I would also like to thank both anonymous referees for their constructive criticism. Different aspects of this paper were presented at the 11th Quadrennial ISECS Conference, Los Angeles, 2003; the Visual Knowledges Conference, Edinburgh, 2003; and the HSS Annual Meeting, Boston, 2003; and I would like to thank the participants of these conferences for their criticism. This research was funded by the Fund of Scientific Research, Flanders. All translations are my own. 


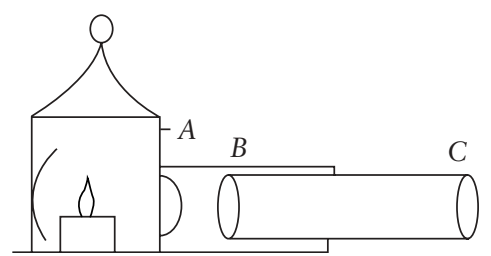

Figure 1. The first sketch of a magic lantern, 'cette lanterne de peur', by Petit in a letter to Huygens (28 November 1662). This figure is an edited version, reprinted in C. Huygens, Oeuvres complètes de Christiaan Huygens, 22 vols., La Haye, 1880-1950, iv, 269. The light of a candle is intensified by the concave mirror; the tube $(\mathrm{BC})$ with two convex lenses magnifies the picture painted on a slide (A). C Koninklijke Hollandsche Maatschappij der Wetenschappen.

converge. ${ }^{1}$ As an optical instrument it embodies the intersection of mathematical, physical and technical 'sciences'. It mediated between educated, popular and courtly cultures, and it had a place in collections, demonstration lectures and texts. In the secondary literature, the magical qualities of the lantern are often unmarked or taken for granted. The magic lantern is taken as an ancestor of cinema, as an instrument in a demonstration lecture, or as a curiosum provoking wonder. ${ }^{2}$ In this paper, however, different aspects of magic come to the fore. I focus particularly on the relation between magic and illusion. ${ }^{3}$

From the moment of its invention in the 1660 s, probably by Christiaan Huygens, ${ }^{4}$ the magic lantern became part of a Baroque culture which was fascinated by illusion. The purpose of this paper is to place the magic lantern in its context at the turn of the seventeenth century and to link it with other visual forms and devices. I therefore first

$1 \mathrm{I}$ am not so much concerned with the technical details of the instrument itself, nor with a general history of the magic lantern (this is studied extensively in the New Magic Lantern Journal, in the publications of the Magic Lantern Society, and in Laurent Mannoni's excellent book The Great Art of Light and Shadow: Archeology of the Cinema (ed. and tr. R. Crangle), Exeter, 2000). In this paper, I will concentrate on the reactions it evoked and the use people made of it. Furthermore, I will draw some general conclusions about the seventeenth-century use of demonstrations.

2 D. A. Cook, A History of Narrative Film, London, 1996 and Mannoni, op. cit. (1); T. L. Hankins and R. J. Silverman, Instruments and the Imagination, Princeton, 1995, Chapter 3; P. Findlen, 'Jokes of nature and jokes of knowledge: the playfulness of scientific discourse in early modern Europe', Renaissance Quarterly (1990), 43, 321 respectively.

3 It is impossible to define such a complex concept as magic here. Some important aspects in the context of my paper are reference to the occult, the rhetoric of veiling and unveiling, associations with superstition, the summoning of apparitions, reference to the demonic, the world image of hidden references and correspondences, the use of symbols, the creation of wondrous effects and the use of extraordinary instruments (the tradition of artificial or mathematical magic).

4 For a good overview of the history of the magic lantern's invention see Mannoni, op. cit. (1), 34-45. The (slightly outdated) chronology and sources given in F. P. Liesegang, Dates and Sources: A Contribution to the History of the Art of Projection and to Cinematography (ed. and tr. H. Hecht), London, 1986, are also still of interest. The magic lantern was 'invented' by Huygens in 1659, but I would argue that it is somewhat anachronistic to pinpoint a 'true' inventor or instrument. From a present-day standpoint, 'hybrids' were created, combinations of camerae obscurae, lanterns, magic lanterns, solar microscopes, projection microscopes, projection mirrors and projection clocks; and making distinctions was not so easy (e.g. the priority claims by Robert Hooke in 'A contrivance to make the picture of any thing appear on a wall', Philosophical Transactions (1668), 38, 741-3; and by Athanasius Kircher in his Ars Magna Lucis et Umbrae, 2nd edn, Amsterdam, 1671, 768). 
explore the different notions of illusion at work in the seventeenth century. Second, the lantern essentially shows. It is an outstanding example with which to explore the contemporary meaning of 'showing' or 'demonstrating'. Concentrating on the work of Kircher and Vallemont, I argue that there was a particular Baroque type of scientific demonstration, embedded in a magical tradition, which I call 'analogical demonstration'. Third, it has long been thought that Kircher was the inventor of the magic lantern, but the fact that he inserted the 'wrong' pictures in his book has puzzled scholarship for centuries. In this paper, I propose a new solution for the Kircher problem. Furthermore, in my analysis of Kircher's and Vallemont's textual and pictorial use of the lantern, and by considering its metaphysical and natural philosophical contexts, I argue that there was magic involved in the magic lantern in a non-trivial way.

\section{Magic, theatre and illusion}

The seventeenth century was an age of social, political and religious instability and this was expressed in the thought and art of the time. Evans writes, 'Splendour and panache, however, are only half of the story. The other spring of Baroque art lay in insecurity, not confidence. It drew on illusion and allusion: on trompe l'oeil and indirect symbolical expression. ${ }^{5}$ Social uncertainty and anxiety were expressed in a cultural fascination for illusion. Since magic and stage plays were at the apex of illusionism, both became popular. They were even brought together by Shakespeare in A Midsummer Night's Dream and The Tempest and by Corneille in his Illusion comique. Both writers described stage plays that were not managed by directors or playwrights but by magicians and compared the shadows summoned up by magic with the actors in a play.

The concept of performance had always been associated with magic in various ways, but during the Baroque magic became also a persistent theme in theatrical performances. Enchantresses, such as Circe and Armide, were the most frequent mythological characters put on the stage in France. ${ }^{6}$ Theatrical scenes of magical metamorphoses were commonplace as we can see from some posters of the time (Figure 2), which represent demons flying above ruins, enchanted islands and a troop of dragons and devils. Projection shows, a novelty correspondingly imbued with mystery, were even better suited than the theatre to the creation of illusions. These shows were explicitly compared with magical theatres. Loret, for example, wrote about 'une autre Armide', hanging up a white canvas and projecting wonderful appearances similar to a stage play, in the same year that Circe, Medea, Alcine and Armide transformed the countryside and bewitched the people on the stage of the Ballet royal. ${ }^{7}$

5 R. J. W. Evans, The Making of the Habsburg Monarchy 1550-1700: An Interpretation, Oxford, $1979,443$.

6 J. Rousset, La Littérature de l'age baroque en France: Circé et le Paon, Paris, 1954, 261-2 and 266-7.

7 J. Loret, La Muze historique (ed. J. Ravenel), Paris, 1857, 193. Loret's remark is valid for projection shows in general, but his poetical letter is of interest for establishing the alleged inventor of the magic lantern. Loret wrote this letter in May 1656, three years before the 'invention' of the magic lantern, in a text overlooked by Mannoni. It must also be noted that, notwithstanding their convincing arguments, Mannoni's (and Wagenaar's) account of the 'invention' of the lantern by Huygens is not yet generally accepted. For their opinion, see W. A. Wagenaar, 'The true inventor of the magic lantern: Kircher, Walgenstein, or Huygens?', Janus (1979), 66, 193-207; and Mannoni, op. cit. (1), 34-5. The matter is further complicated because 


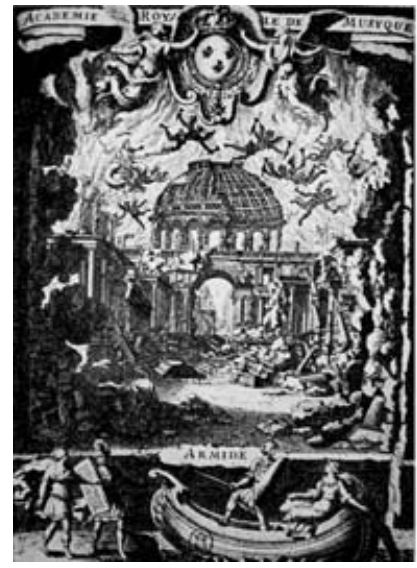

$2-1$
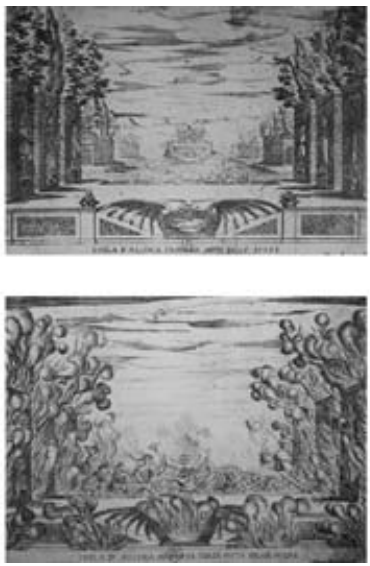

$2-2$
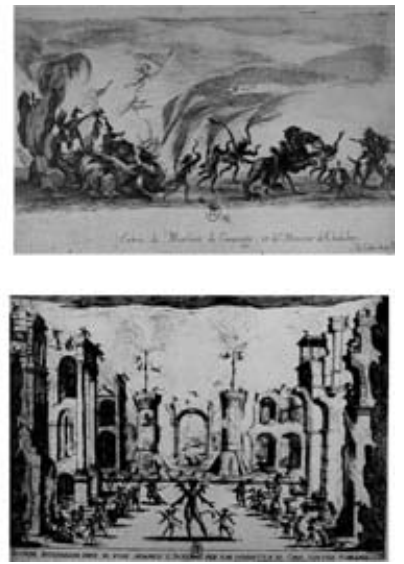

$2-3$

Figure 2. Drawings of Baroque stage scenes and posters, involving transformations, apparitions, magicians and demons, where the enchantresses Alcine, Circe and Armide play an important role. The first plate is the poster of Armide, a play by Bernini performed at the Académie royale de musique, and depicts the arrival of soldiers at a ruin infested with flying demons. The second plate depicts two scenes from a play by Parigi, the sudden transformation of Alcine's magical island from a pastoral place into a blazing hell. The third plate depicts the vendetta between Circe and Tirreno, a scene in a play by Callot. Bibliothèque nationale de France.

The world, too, was compared with a stage play in different ways. In one current metaphor, man was an actor in a play directed by fortune and chance; in another, Nature directed the illusions which tricked the spectators; and in its religious version, God showed his skill and abundance in the theatrum mundi. But man always knew that he was part of the play. ${ }^{8}$ Life itself, and especially courtly life, was also a theatre. Court life resembled a masked ball where appearance had to replace reality. To delude and to dazzle was the art of the courtier, particularly in an absolutist society where courtly rituals became ever more important. ${ }^{9}$

contemporaries often confused descriptions of camera obscura shows with those of lantern shows. Loret introduces the show he describes as a novelty, which is surprising since there was already a public and permanent camera obscura show in Paris from the 1630s onwards, and one might argue that he was present at an early magic lantern show. But his letter in verse suggests that he saw inverted images, which makes no sense for a lantern show. This suggests that Loret witnessed a camera obscura show after all, which would confirm that the lantern was not yet known in 1656.

8 In Shakespeare's As You Like It (1601), and in other secular plays, time and fate play an important role. For the theatre directed by nature see A. Blair, The Theatre of Nature: Jean Bodin and Renaissance Science, Princeton, 1997 (see especially Chapter 5 for a discussion of theatrum mundi metaphors). The most famous play in which God is presented as the ultimate director is probably Pedro Caldéron de la Barca's El gran teatro del mundo (1635), in which multiple metaphors connect the creation of a play to the creation of the world. On the importance of the theatre and theatricality for Baroque culture, and Jesuit culture in particular, see also J.-M. Valentin, Le Théâtre des Jésuites dans les pays de langue Allemande (1554-1680): Salut des âmes et ordre des cités, 3 vols., Bern, 1978; J.-P. Cavaillé, Descartes: La Fable du monde, Paris, 1991; W. H. MacCabe, An Introduction to the Jesuit Theater, St Louis, 1983; and L. F. Norman, The Theatrical Baroque, Chicago, 2001.

9 For centuries the standard handbook of courtly rituals was Castiglione's Il cortegiano (B. Castiglione, La seconda redazione del Cortegiano di Baldassarre Castiglione (ed. Ghino Ghinassi), Florence, 1968). 
In this context, truth was illusory, and scepticism, cynicism, relativism and atheism were present under a veil of orthodoxy. Descartes's malin génie, invoked to turn the whole domain of appearance into illusion, was not just a rhetorical move, but appealed to the sentiments of many contemporaries. ${ }^{10}$ Yet while Descartes was searching for a fixed point in this chaos of delusion, others reconciled themselves to an elusive world. Bernini produced a famous sketch in 1637, The Intermezzo of the Two Theatres. When the curtain rose, the audience saw on the stage another audience, facing them as if to watch a play. Two actors played each for one of the 'audiences', and came to realize that their audience was an illusion for the other. The play in the play, mirror before mirror, appearance after appearance, created a mise en abime where every vantage point disappeared. ${ }^{11}$

As the defenders of a Catholic absolute truth, the Jesuits tried to counter the contemporary sense of illusion by staging their own plays. According to them, the world did not delude, and all knowledge, even the knowledge of God, was only attainable by means of the senses. The Jesuit educational reformer Pontanus (Jacob Spanmüller, 1542-1626) followed Suarez's authority in stating that 'one cannot know God if one does not see the intelligence in the things he created, as the invisible is cognisable by the mind only by means of what is created ' ${ }^{12}$ This commonplace expressed a shared view in seventeenth- and eighteenth-century Jesuit thought. The senses are the necessary basis of all knowledge, knowledge of the transcendent and the invisible included, and it is in sensory experience that we must look for traces of a divine presence that organizes the world. In the theatrum mundi we are all actors and spectators alike, but the Jesuits vigorously opposed the idea that fate or chance conducts the world; God does. ${ }^{13}$

It is this idea that finds its highest expression in the Jesuit theatre. For the Jesuits, a stage play is not an illusionist entertainment but a place where truth is shown, where the invisible is made visible and explicit. They made a strict distinction between imago (true image) and idola (false images, showing something that is not there; an aberration or

10 R. Descartes, Oeuvres de Descartes (ed. C. Adam and P. Tannery), 12 vols., Paris, 1897-1913, vii, 22. The standard book on scepticism is R. H. Popkin, The History of Scepticism from Erasmus to Spinoza, Berkeley, 1979.

11 Rousset, op. cit. (6), 73; and R. Bernheimer, 'Theatrum Mundi', Art Bulletin (1956), 38, 225-47, 243.

12 Pontanus, Progymnasmata latinitatis, 4 vols., Ingolstadt, 1594, i, section 'littera Pythagorae ... ': 'nemo autem cognoscere potest Deum, nisi qui res ab eo conditas intelligentia percepit. Invisibilia enim Dei per ea quae facta sunt intellecta conspiciuntur'. See Valentin, op. cit. (8), 183.

13 For the intellectual cohesion of the Jesuit order and the 'Jesuit ideology' applied to the history of science see especially S. Harris, 'Transposing the Merton thesis: apostolic spirituality and the establishment of the Jesuit tradition', Science in Context (1989), 3, 29-65. In general the Jesuits followed Thomist orthodoxy, from which stems the stress on sensual knowledge. For Aristotelianism and Thomism in Jesuit education see A. Simmons, 'Jesuit Aristotelian education: the De anima Commentaries', in The Jesuits: Cultures, Sciences, and the Arts 1540-1773 (ed. J. O’Malley), Toronto, 1999, 522-37. The stress on contemplating the divine mysteries by means of man's senses is developed at length in Ignatius' Spiritual Exercises, the founding tract of the order (Ignatius of Loyola, The Spiritual Exercises, London, 1955). However, for Jesuit deviations from traditional Thomism see R. Feldhay, 'Knowledge and salvation in Jesuit culture', Science in Context (1987), 1, 195-213; and idem, 'The cultural field of Jesuit science' in The Jesuits: Cultures, Sciences, and the Arts 1540-1773 (ed. J. O’Malley), Toronto, 1999, 107-29, for reflections on the variety of differentiated positions in Jesuit science. O'Malley's edited volume The Jesuits is an interesting recent collection on different aspects of Jesuit culture. 
deformity). ${ }^{14}$ On the stage it is possible to present a true image that counters the illusionism of many plays. They gave a more explicit interpretation of worldly phenomena, and made an invisible order, action or meaning visible and comprehensible for the public. The play of the world is repeated and re-presented with symbolical hints. Avancini's Pietas Victrix (1659), for example, relates the battle for Rome in 312, between the tyrant Maxentius and Emperor Constantinus, invoking magi, dragons, demons, ghosts and an apparition of the Virgin Mary in the clouds. The Habsburg eagle stood as a symbol for piety in its fight with Maxentius' dragon, which was summoned by a magus. The moral is clear, given the context of the Counter-Reformation: the impious tyrant, who took the place of the Christian emperor with the assistance of the devil, will be defeated with God's help.

\section{The illusions of the magic lantern}

'Illusion' had many meanings in the seventeenth century and the concept itself underwent several changes, ${ }^{15}$ which can be seen in the vicissitudes of the magic lantern. From our discussion of the prominent role of magicians in Baroque shows, it is clear that theatrical and projected 'illusions' were closely intertwined with magical apparitions; in what follows, I will show that illusion and magic were also connected in other ways. ${ }^{16}$ First, since antiquity, illusio had been a rhetorical figure, related to irony and allegory. The meaning of the orator was implicit but hinted at; the figure hides and reveals at the same time, ${ }^{17}$ and there is a gap between what is being said and what is really meant. Second, for the Patristic authors the term referred to demonical delusions. Illusio is a deceptive appearance that leads one into error and sin if its nature is discovered too late. It does not disclose a hidden truth but beguiles. This Patristic theme was connected with pietism and spirituality and became widely popular; it appealed particularly to the lower classes where it blended pietism with superstition.

The projected image was new to most spectators and was a reason for bewilderment. ${ }^{18}$ The shadowy projections on the wall resembled dreams, visions or apparitions summoned up by a necromancer, and the devil was widely regarded as the master of such delusions. The effect of strange apparitions was further enhanced by the depicted subject; the prominent theme which leaps to the eye is the monstrous, and monsters, demons and devils were the highlights of the show. Indeed, the typical illusionist capacity of this new apparatus was best accentuated by projecting the 'unreal'. It was the first time that a fantastic and fictional image could be materialized, without becoming as solid as a picture.

14 Denying the image in se was denying the epiphany and the incarnation. The image was central to Catholic culture.

15 M. Hobson, The Object of Art: The Theory of Illusion in Eighteenth-Century France, Cambridge, 1982, Chapter 2.

16 In the course of the paper I discuss several aspects of the general category 'magic' (cf. note 3); its meaning will change accordingly.

17 E.g. Quintilian, The Institutio Oratoria (ed. and tr. H. Butler), 4 vols., Cambridge, MA, 1986, VIII.6.54. See also Findlen, op. cit. (2).

18 For accounts of its reception see Mannoni, op. cit. (1), especially 10-12, 51 and 59-60. 
Projection proved to be a good medium for creating devilish apparitions. Contemporary demonology described demons as incorporeal $;^{19}$ they have no place or form, they only have a 'simple nature'. Notwithstanding their purely spiritual nature, demons are able to form a body out of the elements, using water and earth particles, out of clouds, vapours and exhalations; and they can provide this mixture with more intense colours and a distinct form. Del Rio writes, 'these bodies have no back: it's an imposture \& deceit'. ${ }^{20}$ Older and more popular theories fuelled the people's imagination, rather more than did the opinions of contemporary theology or demonology. Neoplatonism and theurgy posited the pneuma as a sphere between the realms of the objective, the subjective and the intersubjective. The pneuma was semi-spiritual and semi-material and was directly affected by the imagination. ${ }^{21}$ It was the substance of dreams and visions, of apparitions of the dead, and the mode of activity of demons. The imagination of men and demons could be exteriorized. Our most intimate dreams and horrors could be projected, forming visible shapes on this ectoplasm. Verbeke describes it strikingly:

the pneuma has thus the function of a screen on which one can project images from two opposite sides. The material objects of the surrounding world project the contours of their forms on it. On the other side, the side of the demons, the representations of the imagination transform the pneumatic substance according to the lines of their own figure. ${ }^{22}$

The magic lantern brought to the fore this widely disseminated cultural image of demons that could imprint and shape subtle matter. For projectors who wanted to show devilish apparitions, it was an advantage that the projections formed luminous shadows in a dark room, a non-space. The space of the imagination could be occupied by abandoning a natural decor. The stilled and shadowy projections, conjured out of the void, the combination of coloured light rays, suddenly materializing and trying to form a more distinct shape, fitted exactly with the cultural image of an apparition of demons. The creatures of the imagination were conjured into the open. The vive lanterne, the forerunner of the magic lantern, was explicitly compared with the head of a magus filled with 'strange fancies and frenetic imaginations' ${ }^{23}$ Long after people ceased to believe in demonic interventions, monsters and devils remained a prominent theme (Figures 3 and 4) and the operator was often represented as a wizard.

19 Del Rio, Disquisitionum Magicarum, Lyons, 1608, II, q. 28.

20 Del Rio, op. cit. (19), II, q. 28.

21 On the various meanings of the imagination, and on the currency of concepts like the pneuma, see K. Vermeir, "The "physical prophet" and the powers of the imagination, part I: a case-study on prophecy, vapours and the imagination (1685-1710)', Studies in History and Philosophy of Science (2004), 35C (4) (561-91), and the literature cited there.

22 G. Verbeke, L'Evolution de la doctrine du pneuma, du stö̈cisme à Saint Augustin, Louvain, 1945, 372: 'Le pneuma fait donc fonction d'un écran sur lequel on peut projeter des images des deux côtés opposés, les objets matériels du monde environnant y projettent les contours de leur forme; d'autre part, chez les démons, les représentations de l'imagination transforment la substance pneumatique d'après des lignes de leur propre figure.'

23 Garasse cited in D. Kahn, 'The Rosicrucian Hoax in France (1623-4)', in Secrets of Nature: Astrology and Alchemy in Early Modern Europe (ed. W. R. Newman and A. Grafton), London, 2001, 235-344, 281: ' $i l$ semble en les lisant que la teste de cet homme [Paracelsus] fust comme une vive lanterne remplie d'estranges fantaisies, \& d'imaginations frenetiques'. 


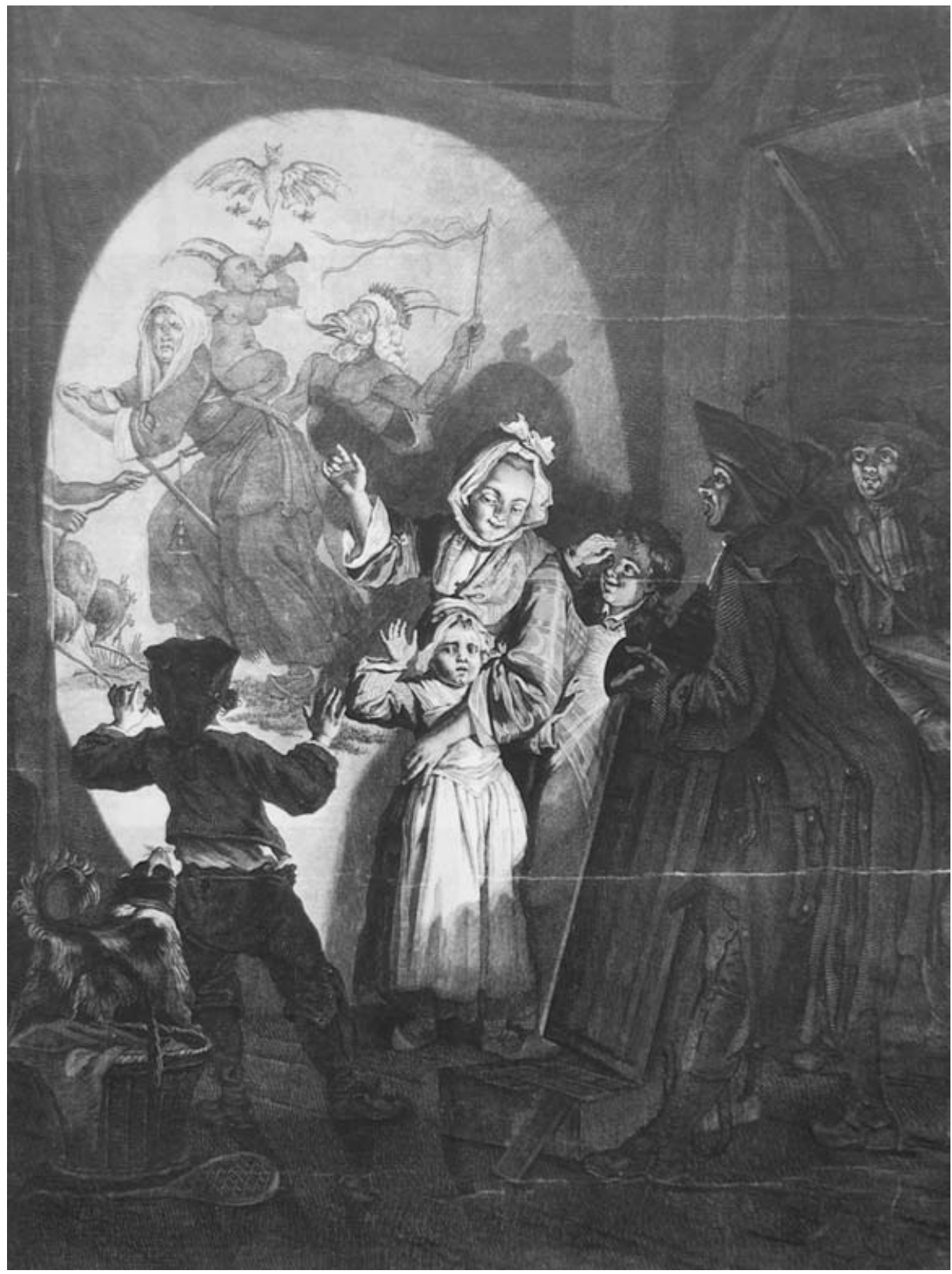

Figure 3. Magic lantern show, performed by a magician; Danish engraving, c. 1725. From the collection of Werner Nekes, reproduced with his permission.

The meaning of 'illusion' as a rhetorical figure, in contrast with its interpretation as a demonical delusion, was also strongly present in the use of the magic lantern. Seventeenth-century courts were driven by a sense of curiosity about the marvellous. 


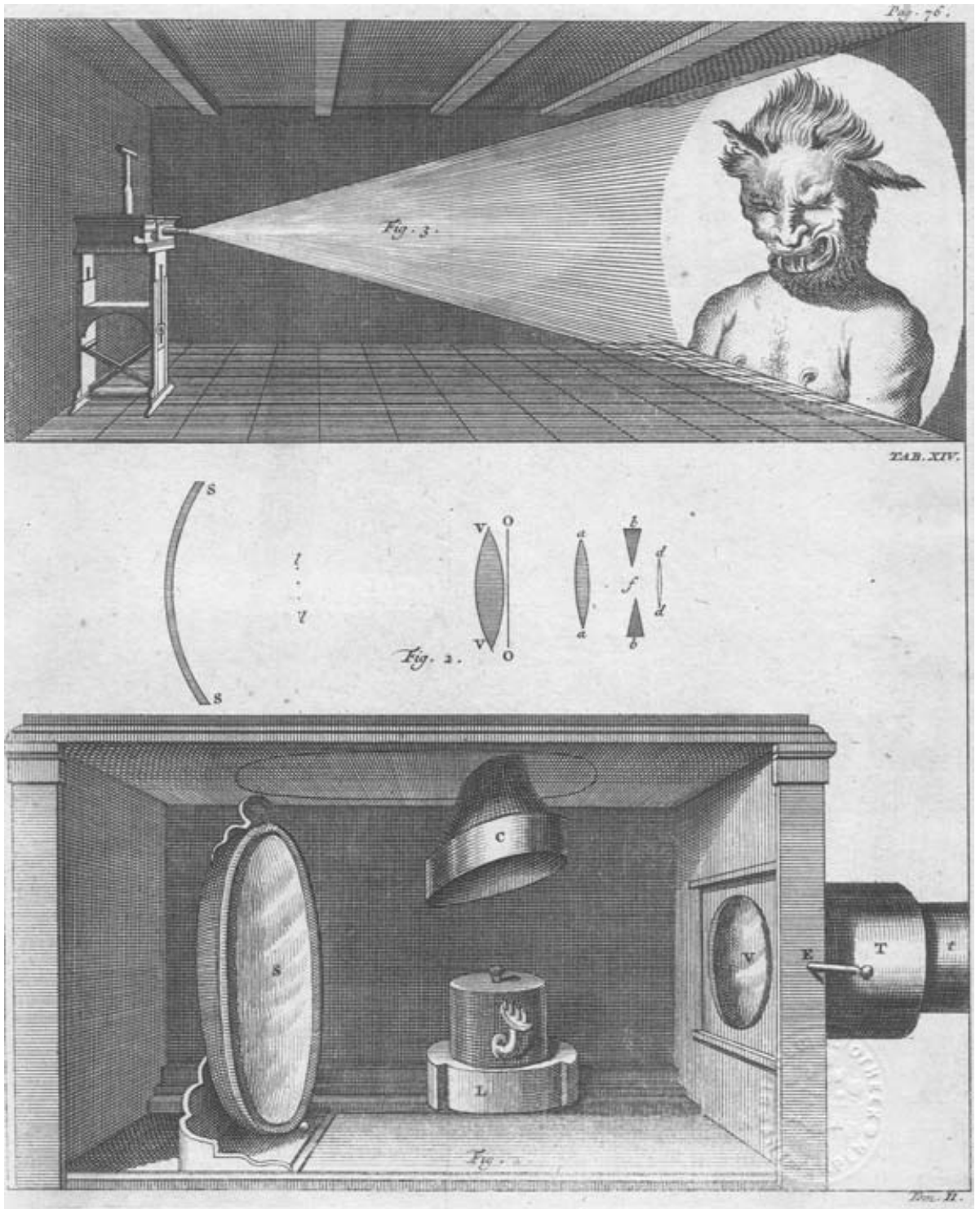

Figure 4. Monsters appeared wherever a magic lantern was installed. Even 'sGravesande's illustration of a magic lantern (1721), drawn in a serious book on scientific demonstration lectures, projects a deformed monster. See W. J. S. van 'sGravesande, Physices elementa mathematica, experimenta confirmata, 2 tomes in 1 vol., Leyden, 1721-5, ii, 76 (Plate 14, located at the back of the book). Source: Stadsbibliotheek Antwerpen.

The magic lantern was the latest novelty. Walgenstein, a travelling projector, demonstrated it at several courts, and many noblemen bought it to supplement their collections of natural and artificial wonders. It disseminated rapidly. Kircher wrote that Walgenstein ' had sold it to various princes in Italy, so that it was already commonplace 
in Rome', ${ }^{24}$ while Vallemont attested that 'this machine has provoked a lot of rumour for a while' ${ }^{25}$

As Daston and Park have shown, the monstrous and the marvellous became imbued with scientific curiosity and formed an essential part of the 'scientific' reform and selfdefinition of natural philosophy. The jokes of nature became intertwined with jokes of knowledge in Kircher's texts and in his museum, which he compared with a 'Mundi theatro' ${ }^{26}$ The magic lantern found its place in a section on magic which included 'quicquid rarum, curiosum, paradoxum, prodigiosumque' ${ }^{27}$ But illudere as rhetorical figure implies more than just a joke, a trick or a jest. It is also an allusion (alludere) to a deeper meaning. Artificial wonders which tricked and deluded the spectators were much in vogue at court. They were a part of the courtly play of simulating and dissimulating. Kircher made a catoptrical device which reflected the body of the spectator, with his head substituted by an animal head (Figure 5). It thus held up a mirror, with a moral message to the courtier, who could not distinguish his mask from his real face. 'I doubt who I am', 'I am disguised for myself', were fit expressions for this form of life. ${ }^{28}$ But the issue was not mainly moral. There are also famous accounts of Queen Christina of Sweden, who came to visit Kircher's and Hesselin's 'enchanted' and 'illusionist' collections a few months after she had abdicated and was converted to Catholicism. ${ }^{29}$ This might point to deeper layers of meaning; such a deeper meaning, I will argue, is also present in the demonstration of the magic lantern.

\section{Kircher's magic lantern and the visualization of the invisible}

Not coincidentally, the first publications containing a description of the magic lantern were by Jesuits. ${ }^{30}$ Eschinardi wrote a brief and scientific account in 1668 . In 1671 the polymath Athanasius Kircher (1602-80) added a description of a primitive magic

24 A. Kircher, op. cit. (4), 768: 'diversis in Italia principibus venditit, ut proinde jam Romae res poene vulgaris sit'.

25 P. (le Lorrain de) Vallemont, La Physique occulte, Paris, 1693, 402: 'cette machine a bien fait du bruit depuis quelque tems'.

26 Letter of Kircher to Anckel, Rome, 16 July 1659, cited in the unabridged draft of M. J. Gorman's very rich paper 'Between the demonic and the miraculous: Athanasius Kircher and the Baroque culture of machines', at http://www.stanford.edu/group/shl/Eyes/machines/, 2. The abridged paper is published in D. Stolzenberg (ed.), The Great Art of Knowing, Stanford, 2001, 59-70. An almost unabridged Italian translation (co-authored with Nick Wilding) can be found in E. Sardo (ed.), Il Museo del Mondo, Rome, 2001, 217-37. In this paper I refer to the online article. For jokes of knowledge and jokes of nature see P. Findlen's excellent article 'Jokes of nature and jokes of knowledge', op. cit. (2).

27 Kircher, op. cit. (4), 769: 'something rare, curious, paradoxical and prodigious'.

28 Rousset, op. cit. (6), 230: 'Je doute qui je suis'; 'Je suis à moi-même déguisé.'

29 For Christina's visit to Hesselin see Hobson, op. cit. (15), 23; and J. Baltrušaitis, Anamorphic Art (tr. W. J. Strachan), New York, 1977, 57-8; for her visit to Kircher see Gorman, op. cit. (26), 20-2; and idem, "From "the eyes of all" to "useful quarries in philosophy and good literature": consuming Jesuit science, 1600-1665' in The Jesuits: Cultures, Sciences, and the Arts 1540-1773 (ed. J. O'Malley), Toronto, 1999, 170-89.

30 There were accounts by the Jesuits Eschinardi in 1668, Kircher in 1671, Dechales in 1674, De Sepibus in 1678, Kestler in 1680 and Kirchmaier in 1680. 


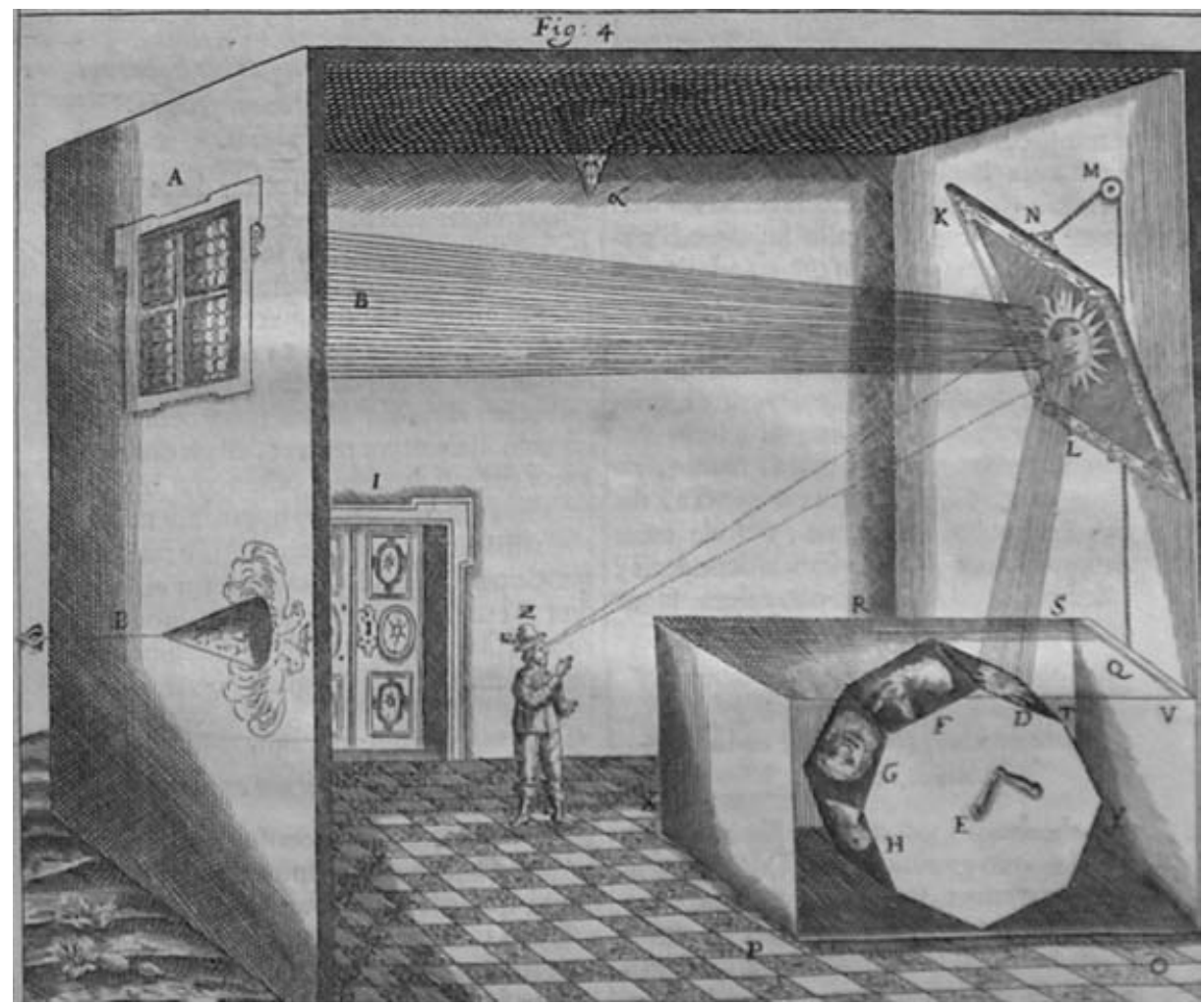

Figure 5. Kircher's metamorphosis machine, in A. Kircher, Ars Magna Lucis et Umbrae, Amsterdam, 1671, 783 (901 in the 1646 edition). The spectator $(Z)$ sees himself in the mirror (L), but on his reflected body appears a sun or the head of an animal. Eight different heads could be made to appear by rotating the wheel (E). Note also the conical anamorphosis (see also the upper part of Figure 9 below) of the Habsburg two-headed eagle on the left wall $(\beta)$ and on the ceiling $(\alpha)$. Courtesy of the Library of Theology, Leuven University.

lantern and two (wrong) figures to his second edition of the Ars Magna (see Figures 12a and $12 \mathrm{~b}$, and the caption). ${ }^{31}$ Despite its defects, Kircher's account became widely influential and shaped the reception of the lantern. For centuries the invention of the lantern would be attributed to him. Kircher's work is nowadays difficult to interpret. For a modern reader it contains barely any scientific information of interest and he is seen as an exponent of a decaying Jesuit and Italian science. Kircher not only wrote about the lantern but also displayed it in his museum. ${ }^{32}$ In the seventeenth

31 It should be acknowledged that the magic lantern was not essential to the purpose of the Ars Magna, since the book was written when it was not yet invented. But the rigour with which Kircher defended the priority of his idea in 1671 proves that it fitted in rather well (see Kircher, op. cit. (4), 768, see also note 4 above and note 40 below).

32 Kircher, op. cit. (4), 769. See also the catalogues of his museum: G. De Sepibus, Romani collegii Societatis Jesu musaeum celeberrimum, Amsterdam, 1678; and F. Buonanni, Musaeum Kircherianum, 
century his collection of antiquities, naturalia and machines was famous and visited by royal and courtly patrons. The texts and illustrations in his publications mirrored the devices physically present in the museum. Many of his instruments were then (re)presented in three different ways: textual, visual and physical. None of these (re)presentations had primacy, but they were closely intertwined and reinforced each other. ${ }^{33}$

Kircher's books and the Musaeum Kircherianum are both theatres of knowledge, and the Ars Magna was an encyclopaedic enterprise to compile all knowledge about light and shadow. Yet its aim was even more ambitious: Kircher wanted to set out a theory of the whole cosmos. To guide the reader into this labyrinth, the Ad lectorem provides a clue to reading the book: it asserts that the ten chapters correspond to the ten Cabbalist Zephirot. Other clues also indicate that the work should be read on a symbolic level. There is the further allusion to Cicero's story of a man who finds a thole-pin (a very small part of a boat) and became infatuated with the idea of building himself a boat attached to it. In the same way, starting with the study of light will lead us through the whole cosmos. ${ }^{34}$ Kircher identified himself with Hermes, the sage who handed down the arcane knowledge in symbolic form. It is clear that Kircher, 'a new Hermes for a new Egypt', as Paula Findlen characterizes him ${ }^{35}$ imbued his own message with his own symbolism (Figure 6). Here, in the Ars Magna, it is the epilogue which proves to be the most interesting starting point for a symbolic reading.

In the epilogue the metaphysics of light is explained. In a surprisingly Platonist vein (for a Jesuit), Kircher explains that God or the Platonist Good are symbolized by the sun or the absolute light. The Neoplatonist emanation is symbolized as the diffusion of the absolute light (lux) into secondary light (lumen). This emanation proceeds in different stages, symbolized by reflection and refraction in mirrors and lenses. Angels are symbolized by a first mirror or lens and man by a second. All light comes from God and is dispersed in the world by reflection and refraction. The first or angelic mirror or lens is bright and clear, and is without image or form (just like the sun). The second (human) mirror or lens is already in shadow and causes a further dispersion of the light. Those shadows, however, have a more distinct shape and form (just like the shadows on the

Rome, 1709, 311-12. In the history of the Collegio Romano, in which important visits to the college are described, the magic lantern was first mentioned in the description of a visit by the prince of Neuburg in 1676. See R. García Villoslada, Storia del Collegio Romano dal sua inizio (1551) alla soppressione della Compagnia di Gesù (1773), Analecta Gregoriana 66, Series facultatis historiae ecclesiasticae, sectio A 2, Rome, 1954, 278.

33 See my forthcoming paper 'Athanasius Kircher's magical instruments: an essay on applied metaphysics and the reality of artefacts' for a more elaborate discussion.

34 Kircher, op. cit. (4), preface: and with the boat, made of the thole-pin, 'maria tranavit, ingentes divitias acquisivit'.

35 P. Findlen, Possessing Nature: Museums, Collecting, and Scientific Culture in Early Modern Italy, Berkeley, 1996, 339. Ingrid Rowland describes, in The Ecstatic Journey: Athanasius Kircher in Baroque Rome, Chicago, 2000, 15-17, the function of Harpocrates in Kircher's work. Harpocrates, a figure originating in a misinterpretation of antique sources, was an infant god. Raising his finger to his lips as an injunction to silence, in this way insisting that true wisdom shunned expression of the naked truth, Harpocrates is taken by Rowland as an emblem of Kircher's oeuvre. 


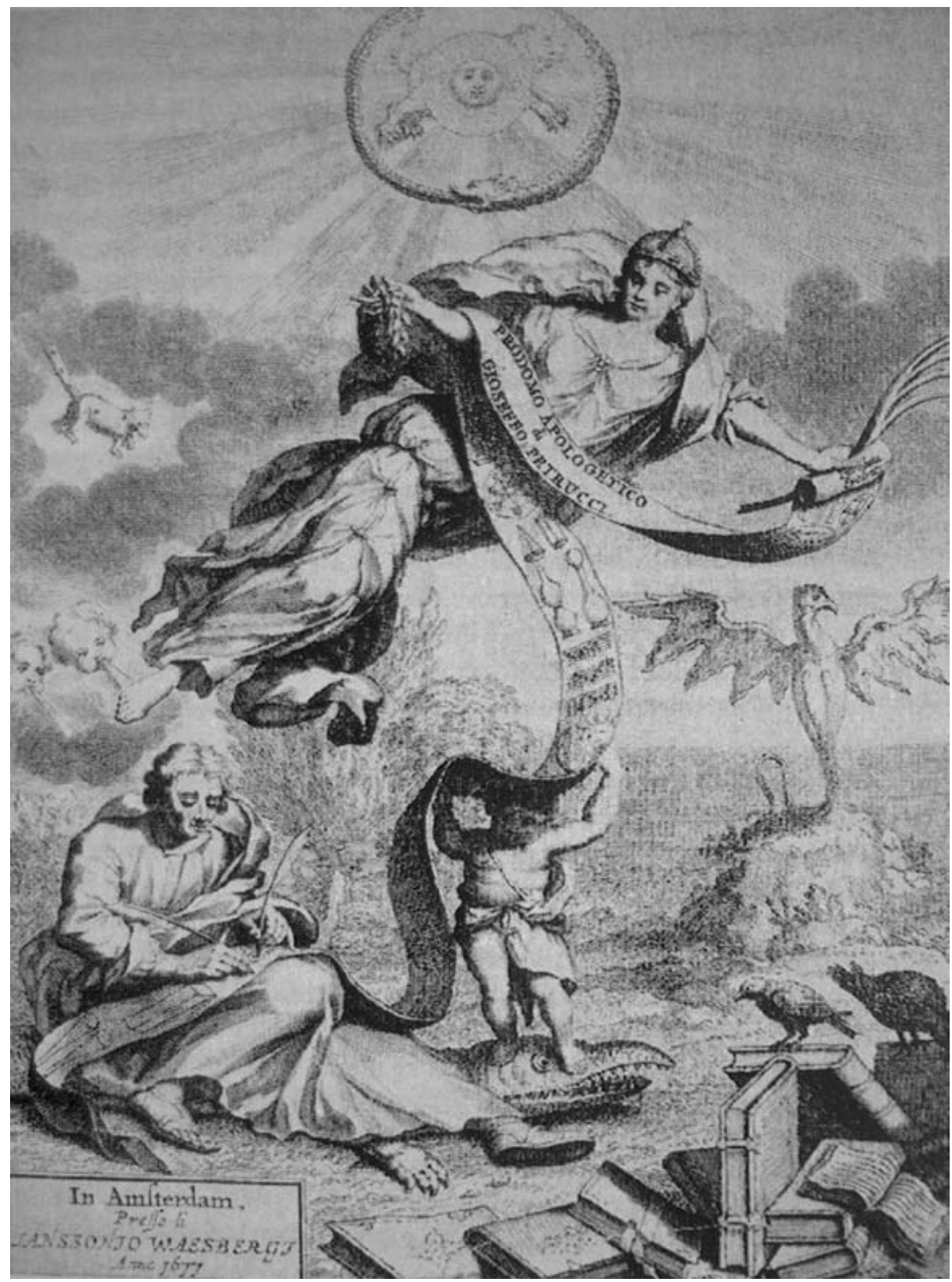

Figure 6. Kircher depicted as a new Hermes Trismegistus, surrounded by symbols and marvels; in Gioseffo Petrucci, Prodomo apologetico alli studi Chircheriani, 1677, frontispiece. Findlen explains that 'the portrayal of Kircher as a scribe underscores his comparison with Hermes, scribe of Osiris'. In this frontispiece more symbols are employed, such as Kircher sitting on a crocodile, symbol of the difficulty of his studies, and below a solar lion, symbol of Osiris and the fecundity of nature. Courtesy of Leiden University Library. 
moon) than the bright light of the heavens. ${ }^{36}$ Man is thus at home in a cloudy, distorted and shadowy world, some paces away from the original light, and if he aspires to see this light he is blinded. Kircher deviates here from the Neoplatonists by asserting that knowledge is always informed by the senses and by the shadowy world ${ }^{37} \mathrm{He}$ affirms the tenet of his order when he denies direct divine and mystical enlightenment. It is in the world that we can find various signs which refer to God or lux. Light is 'the most admirable essence, the occult symbol of the universe, by which, according to a certain wonderful proportion, the highest things are connected to the lowest, the lowest to the middle, the middle to both the highest and the lowest ${ }^{38}$

This is the metaphysical framework within which we have to understand the body of Kircher's work. It is clear that we cannot interpret his experiments as hypotheticodeductive tests of his theories, because Kircher's metaphysics and his world image are as fixed as an axiom. I propose then to see his descriptions of devices as a real cabinet or theatre of curiosa, each of which tells us in another way something about the universe. But it is a truly Jesuit theatre, creating an imago, not an idola. His work is part of a Baroque rhetoric which uses the figure of the 'illusion' to reinforce a Catholic message. The illusion (il-ludere) is elusive (e-ludere) but also allusive (al-ludere) and points to a hidden meaning and a higher reality. The prodigious is used as a kind of portent, not in the vulgar way as an omen, but as a sign which makes God's invisible presence visible. His theatre demonstrates, but not in the sense of experimenta crucis; it displays and shows, and we might try to discover the meaning of some of his curiosities. ${ }^{39}$

The first considered here is the new cryptology, or the art of sending secret messages by means of mirror projection. Kircher considered this art very similar to the magic lantern, since he based his claim for his invention of the lantern on this device (Figure 7). ${ }^{40}$ The upper figure represents the device in all its simplicity: a mirror, on which something is written backwards, and a lens. The lower figure depicts how this device is used: a strong light source (e.g. the sun) illuminates the mirror, the beam of light passes through the lens, and a straight image is projected in a darkened room (note that the different light beams do not modify each other). This apparatus was one of the optical devices

36 See especially epichirema 4 and 5. Normally God is identified with the sun. Confusingly, angels are sometimes also symbolized by the sun and man by the moon (and there is also one reference to a divine mirror). This already indicates the shifting metaphors and the slight shifts in meaning throughout the text (e.g. in the descriptions of the emanatio and the recollectio), but the general structure is clear. For Kircher's metaphysics, see also my forthcoming paper, op. cit. (33).

37 It is like Plato's cave, but now one cannot escape. One has to learn to decipher the special shadows, cast by some good higher beings (angels).

38 Kircher, op. cit. (4), 1: 'maxime admirandam essentiam, occultum Universi symbolum, quo summa imis, ima mediis, media denique imis, summisque mira quadam ratione connectantur'.

39 It is instructive to read North's chapter on the difficulties of interpretation (aptly called 'Strange devices') in this respect; see J. North, The Ambassadors' Secret: Holbein and the World of the Renaissance, London, 2002, Chapter 5.

40 For the comparison between this instrument and the magic lantern, see Kircher, op. cit. (4), 768. In 1654 the Jesuit mathematician Andreas Tacquet used a similar instrument to demonstrate Martinus Martinius's missionary travels from China to Belgium in a show strongly resembling a magic lantern show. 


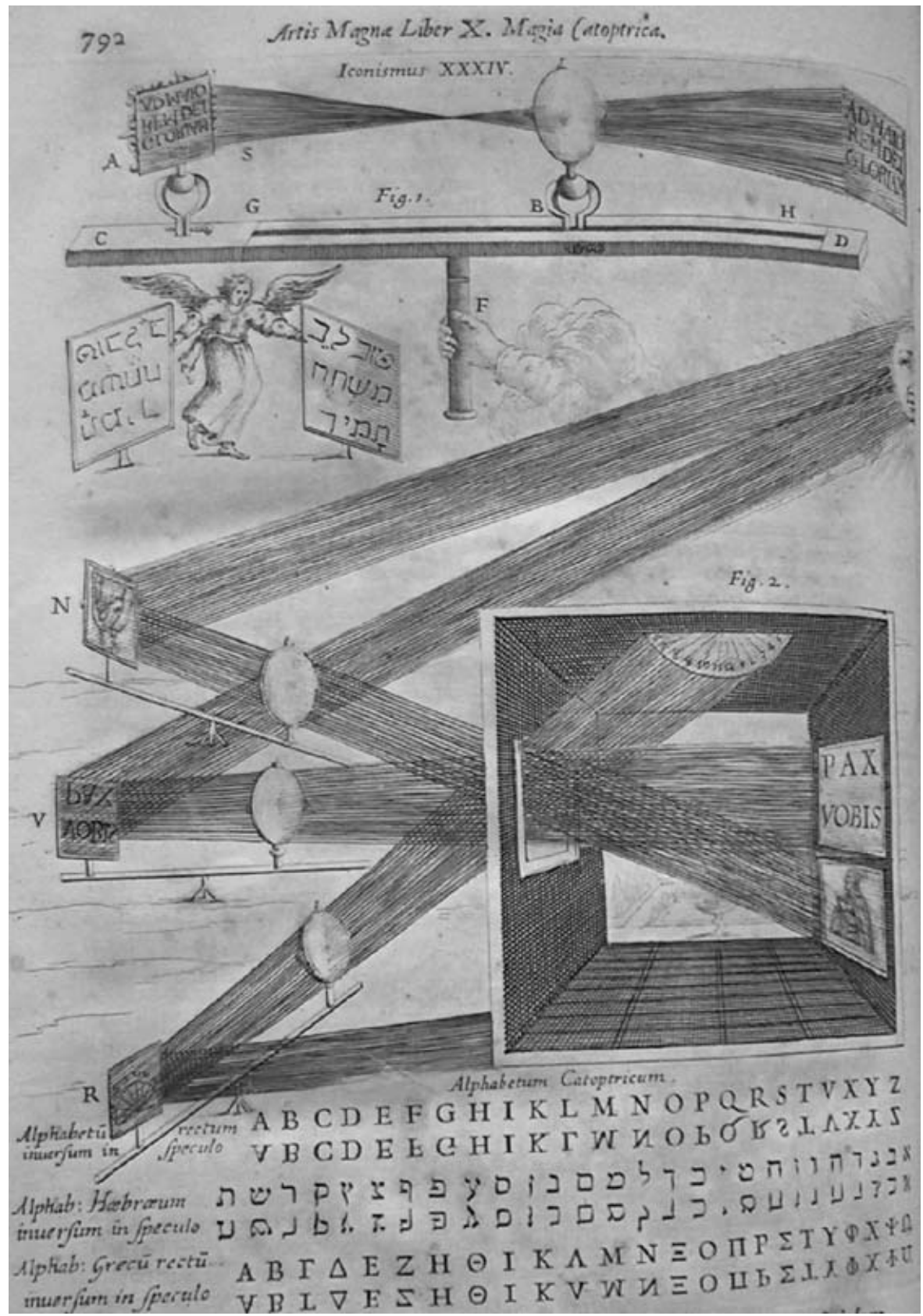

Figure 7. Kircher's engraving of the art of mirror writing (or projecting), which Kircher considered to be very similar to the magic lantern. A. Kircher, Ars Magna Lucis et Umbrae, Amsterdam, 1671, 792 (912 in the 1646 edition). Note the prominence of religious messages and Hebrew, written on the mirror, and compare this with the cryptic religious warning in Figure 8 below. Mirror projecting (employed by the arm of God, as shown in the picture), was not used to show monsters but to pass holy messages (angels as messengers) to the world. Courtesy of the Library of Theology, Leuven University. 


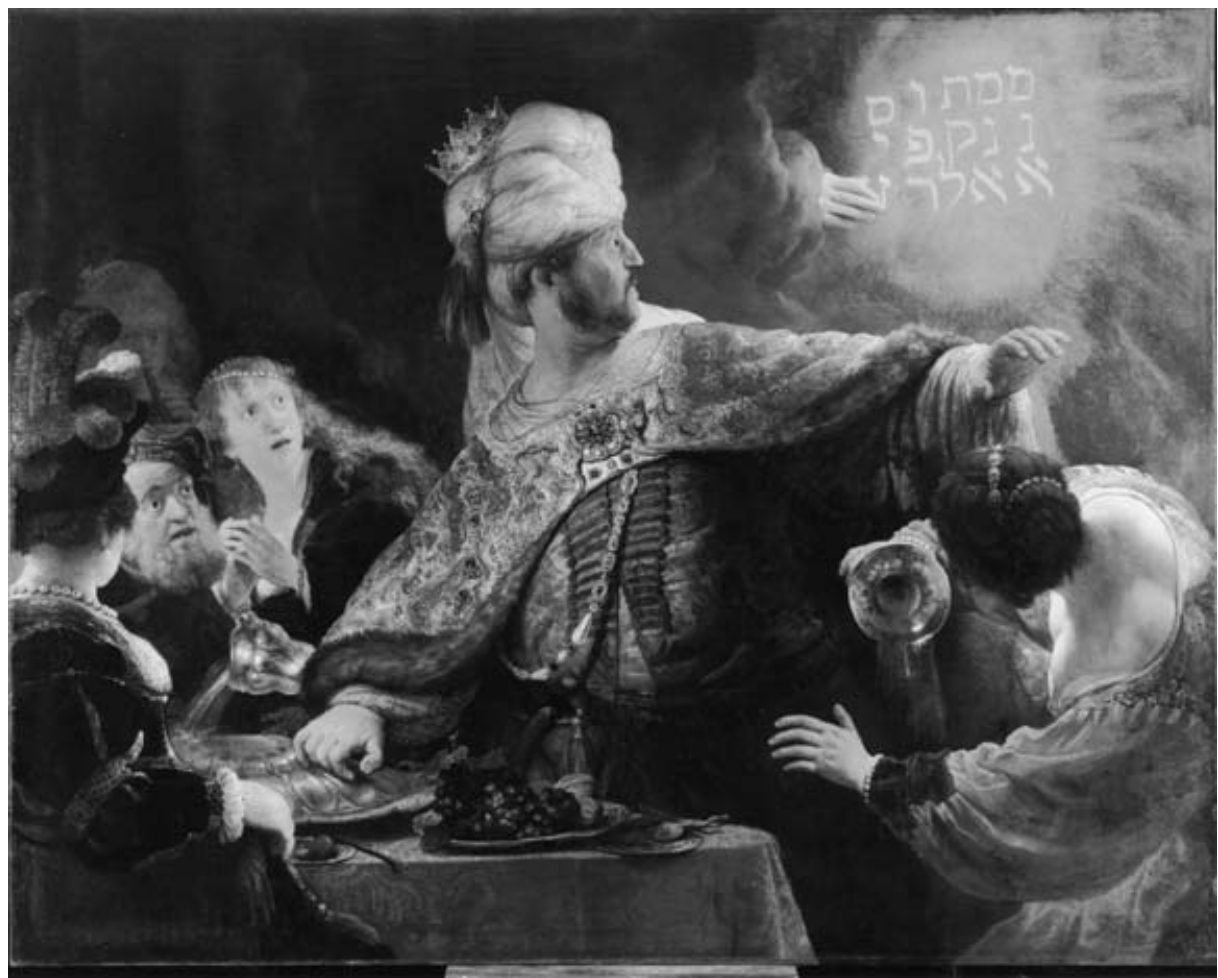

Figure 8. Rembrandt's painting of Belshazzar's Feast (dated c. 1635) shows the effect of mirror writing, writing luminous letters on a wall by means of a mirror. Courtesy of the National Gallery, London.

popular for demystifying godly or demonic apparitions. ${ }^{41}$ Rembrandt's painting Belshazzar's Feast (Figure 8) shows the sudden appearance of flaming letters on a wall. This magical writing was accomplished by a device similar to Kircher's description. A strongly illuminated mirror covered with dust is used. When one wipes off this dust with a finger, luminous letters will be projected on the wall. Dispersion of the light will also cause the fingers to be projected. This writing hand will be partially visible, as in Rembrandt's painting. It will seem disembodied, appearing out of the void and disappearing into the dark. ${ }^{42}$

41 Stories of strange and magical apparitions are ancient. Pliny's Natural History ushered in a tradition of demystification that explained away apparitions by referring to projection instruments, and there existed a whole literary tradition (Chaucer, Marlowe, Cellini) embroidering on this theme; see H. Hecht, 'The history of projecting phantoms, ghosts and apparitions, part 1', New Magic Lantern Journal (1984), 3, 2-6. For the seventeenth-century debate regarding biblical apparitions and the magic lantern see A. van Dale, De oraculis veterum ethnicorum, Amsterdam, 1683; B. Fontenelle, History of Oracles, London, 1688; Vallemont, op. cit. (25), 552-6.

42 Rembrandt's etching Faust (c. 1652) depicts a similar mysterious projection. Many devices for projecting letters in a dark room were constructed by Schwendter and Kircher, amongst others, in the period between 1630 and 1670. The remarkable correspondence between Rembrandt's detailed execution of 


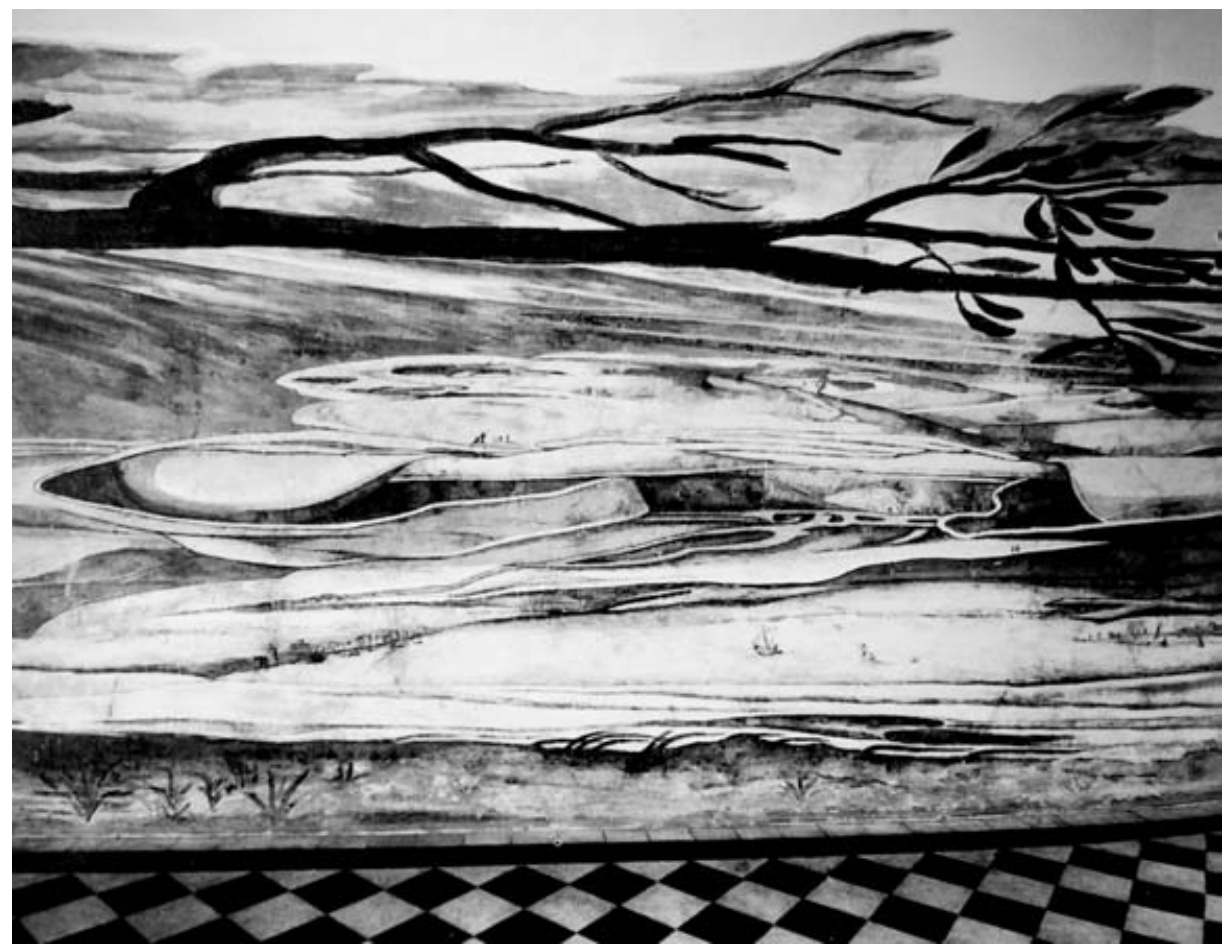

(a)

Figure 9a. Front view of an anamorphosis, depicting a landscape with deltas and bridges, little boats and a harbour. Painting by Emmanuel Maignan, in the cloister of S. Trinità dei Monti, Rome, 1642. Normal perspective shows an image with depth for a spectator in front of the image; an anamorphosis is a distorted image made by a distorted perspective by moving the perspective point from the centre to the side. The deformed image is often camouflaged by depicting little figures in unintelligible forms to give these forms sense and to hide the true image. This true image can be seen by looking at the picture from one side. Reproduced with permission of Alessandro Vasari.

We can see the metaphysics of light clearly at work in Kircher's engraving (Figure 7): the $\ln x$ (sun) is refracted by a mirror (angel), with a secret message inscribed (angel as bearer of God's messages), and dispersed by a lens (man) causing a shadowy image to appear (world), which contains a Hebrew message (secret symbols hidden in the world). Looking straight into the light would blind us (the mistake of mysticism), but deciphering the secret signs on the screen (in the world) will give us a key to the truth (Jesuit religious message). Note that the angel, who is drawn above the device, is holding the mirrors with secret messages; this makes the iconographical identification of the angel and the mirror almost explicit. In the upper part of the picture, God's hand supports the whole cosmic system: angel-man-world.

wondrous apparitions and the effects of optical projection apparatus suggests interesting new perspectives for the current debate on the relationship between optics and art, as incited by David Hockney's and Charles Falco's thesis. I will elaborate on this in another paper. 


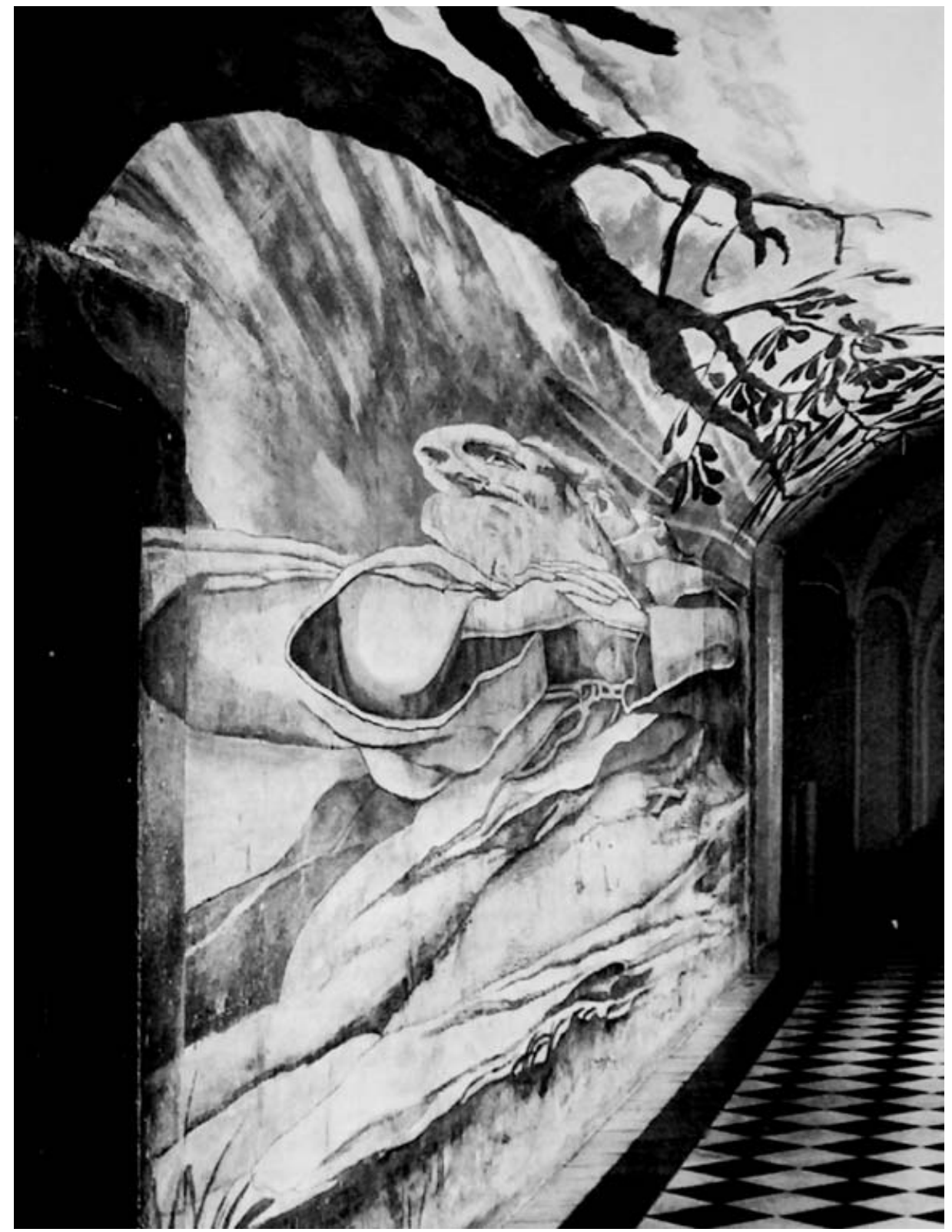

(b)

Figure 9b. The same fresco, seen from the side, which renders the hidden saint visible. Reproduced with permission of Alessandro Vasari.

Another example is anamorphosis, a special perspectival technique (Figure 9). ${ }^{43}$ This art gained new force and popularity in the seventeenth century, especially in

43 Baltrušaitis, op. cit. (29), gives many images but little interpretation. 
Catholic orders, and was a powerful means to express a moral or religious message. Secular anamorphoses often expressed a vanitas or theatrum mundi symbolism. Seen from one perspective, one sees a famous, powerful and rich person; seen from another perspective, a skull appears. Reflected in a cylinder one sees the head of a king (Figure 10a); when the cylinder is taken away, a skull appears, and the only remnant of the king's image is a formless and monstrous shape (Figure 10b). The skull floating in the foreground of Holbein's The Ambassadors is notorious. ${ }^{44}$ Christian anamorphoses, on the other hand, contained images of saints or of the baptism of Christ, as can be seen in Figure 9b. But the Jesuits, warriors of the Counter-Reformation, depicted the Habsburg eagle or the Papal dove (Figure 11), pregnant with political meanings.

Yet the symbolical meaning of the anamorphic technique in se was even more important than the content of the picture. Paradoxically, normal perspective was only an empty copy of the world (idola), but deformed perspective unleashed a hidden truth (imago). ${ }^{45}$ This truth is that there exists a special perspective which renders the invisible image (the divine) visible. This was the meaning of anamorphosis: in the deceitful and chaotic world (distorted lumen), you can see a secret order with a (divine) message, if viewed from a certain (Catholic) perspective. This perspective was part of the optical or religious knowledge which the Jesuits possessed, by which they affirmed their priority of interpretation of worldly phenomena. ${ }^{46}$

44 See J. North, op. cit. (39), for many more meanings that one can find hidden in the painting. North is somewhat disparaging about a memento mori reading (192-6).

45 There was a controversy in France about the moral value of normal and deformed perspective. The Academy of Arts argued, following classical artistic principles, that deformed but recognizable images were morally bad. The religious orders, however, who made most of the anamorphoses, did not agree. If one accepted the Platonist critique on realist images, the possibility of hidden perspectives held the promise of a symbolic and allegoric play with meanings. Seen from this perspective, art could create morally meaningful images instead of empty copies of the world.

46 Such an interpretation of anamorphoses was not often made explicit, but it was clearly stated in a devotional text by Bossuet. In his sermon 'Sur la providence' (1662) he sets out to counter the libertines, 'ces nouveaux Samaritains', who denied all divine providence because of the disorderly state of this world. For them, the unjust distribution of good and bad shows that the world is governed only by fate. Bossuet replies, 'Quand je considère en moi-même la disposition des choses humaines, confuse, inégale, irrégulière, je la compare souvent à certains tableaux, que l'on montre assez ordinairement dans les bibliothèques des curieux comme un jeu de la perspective. La première vue ne vous montre que des traits informes et un mélange confus de couleurs, qui semble être ou l'essai de quelque apprenti, ou le jeu de quelque enfant, plutôt que l'ouvrage d'un main savante. Mais aussitôt que celui sait le secret vous les fait regarder par un certain endroit, aussitôt toutes les lignes inégales venant à se ramasser d'une certaine façon dans votre vue, toute la confusion se démêle, et vous voyez paraître un visage avec ses linéaments et ses proportions où il n'y avait auparavant aucune apparence de forme humaine. C'est, ce me semble, messieurs, une image assez naturelle du monde, de sa confusion apparente et de sa justesse cachée, que nous ne pouvons jamais remarquer qu'en le regardant par un certain point que la foi en Jésus-Christ nous découvre. ... Quelle est la confusion de ce tableau! et ne me semble-t-il pas que ces couleurs aient été jetées au hasard, seulement pour brouiller la toile ou le papier ... . Le libertin inconsidéré s'écrie aussitôt qu'in n'y a point d'ordre ... . Mais arrêtez, malheureux, et ne précipitez pas votre jugement dans une affaire si importante. Peut-être que vous trouverez que ce qui semble confusion est un art caché; et si vous savez rencontrer le point par où il faut regarder les choses, toutes les inégalités se rectifieront, et vous ne verrez que sagesse où vous n'imaginiez que désordre.' J. B. Bossuet, Sermons choisis (ed. A. Rébelliau), Paris, 1901, 243-5 (my emphasis). 


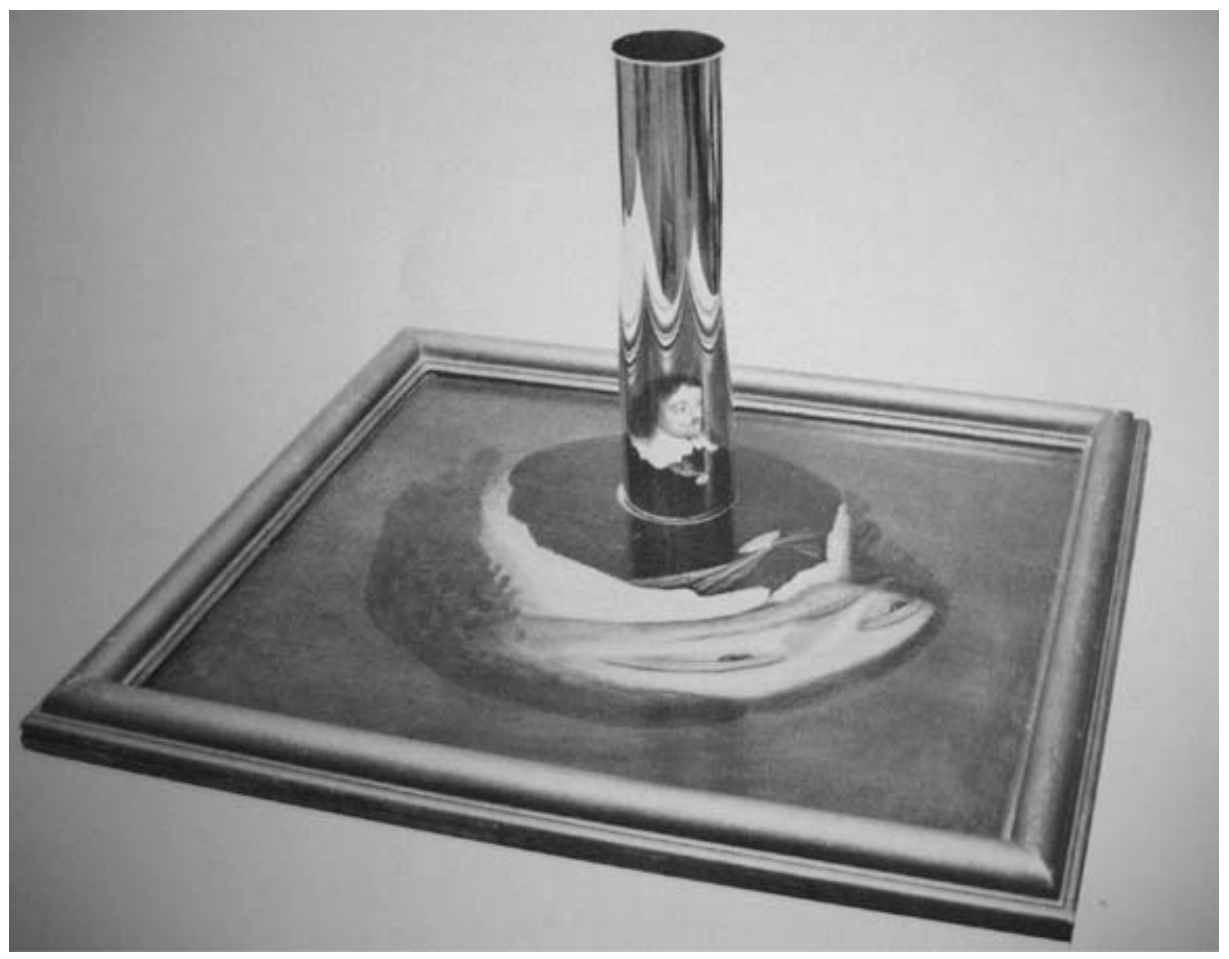

(a)

Figure 10a. Anamorphosis with cylindrical mirror, in which the portrait of Charles I is visible (c. 1649). (C) Swedish Portrait Archives (Grispholm 2527).

Similar explanations can be given for other devices described in the Ars Magna, such as the numerous sun clocks Kircher describes. In the case of the sun clock, the sun (divine or angelic truth) casts a shadow (man) on the clock, by which we can measure the world (symbol of human knowledge). It should be remembered that before the vogue of Cartesianism the clock metaphor did not possess a mechanistic meaning, but expressed the divine plan. In the Ars Magna the clock can be seen as a metaphor for the orderly universe, driven by the metaphysical (occult) power of lux/lumen.

It is in this context that we find the discussion of the magic lantern and the 'wrong' figures inserted (Figures 12a and 12b), in a section just before the metaphysical epilogue. There are good reasons to believe, however, that these figures are not erroneous at all. ${ }^{47}$ Notwithstanding the perils of seventeenth-century print culture, much

47 For the error in the engraving see the discussions in the New Magic Lantern Journal and Mannoni, op. cit. (1), 58. Of course, it can always be argued that these figures are wrong, since mistakes could easily happen in the complex seventeenth-century publishing process, as Adrian Johns has vividly shown (A. Johns, The Nature of the Book: Print and Knowledge in the Making, Chicago, 1998). There is, however, no evidence that in this case any such error occurred and I will account for the unexpected structure of Kircher's instruments 


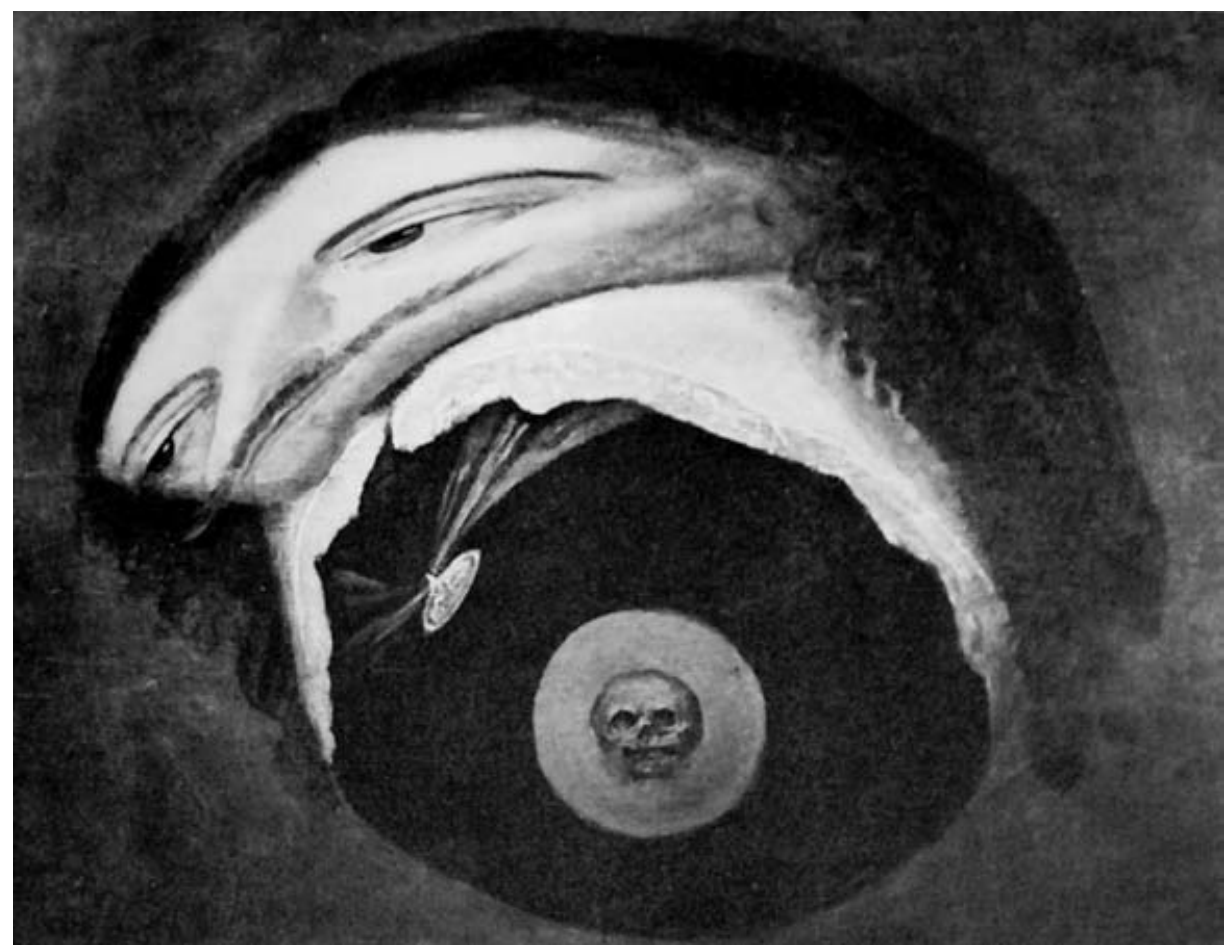

(b)

Figure 10b. The same cylindrical anamorphosis, without the cylinder. Only a deformed image remains and in the middle of this image a skull appears. (c) Swedish Portrait Archives (Grispholm 2527).

attention was paid to these particular engravings. The magic lantern was the only instrument that was represented here in two pictures, stressing its particular importance. Van Waesberge, the prestigious Dutch publisher of the second edition of the Ars Magna, was known for his detailed and accurate maps, and Kircher's lavishly illustrated works were self-consciously executed. Kircher himself attached great importance to his illustrations, which often hid different levels of meaning. This already suggests that the pictures really correspond to Kircher's instruments. Indeed, Wagenaar has shown that the magic lantern drawings in the Ars Magna correspond (with all the right dimensions) to an experimental arrangement. In fact, Kircher's drawings depict an improved point light-source projection which, however, produces quite poor magnification compared with Huygens's instrument. This is also clearly visible in Kircher's figures, where extraordinarily large slides are magnified only four

below. It follows that every identification of these figures as erroneous should be dismissed as anachronistic because such a judgement is based on our expectations of what a magic lantern should be and how it should be used (see also note 4 above, where I argue that it is also anachronistic to look for an 'original instrument'). 


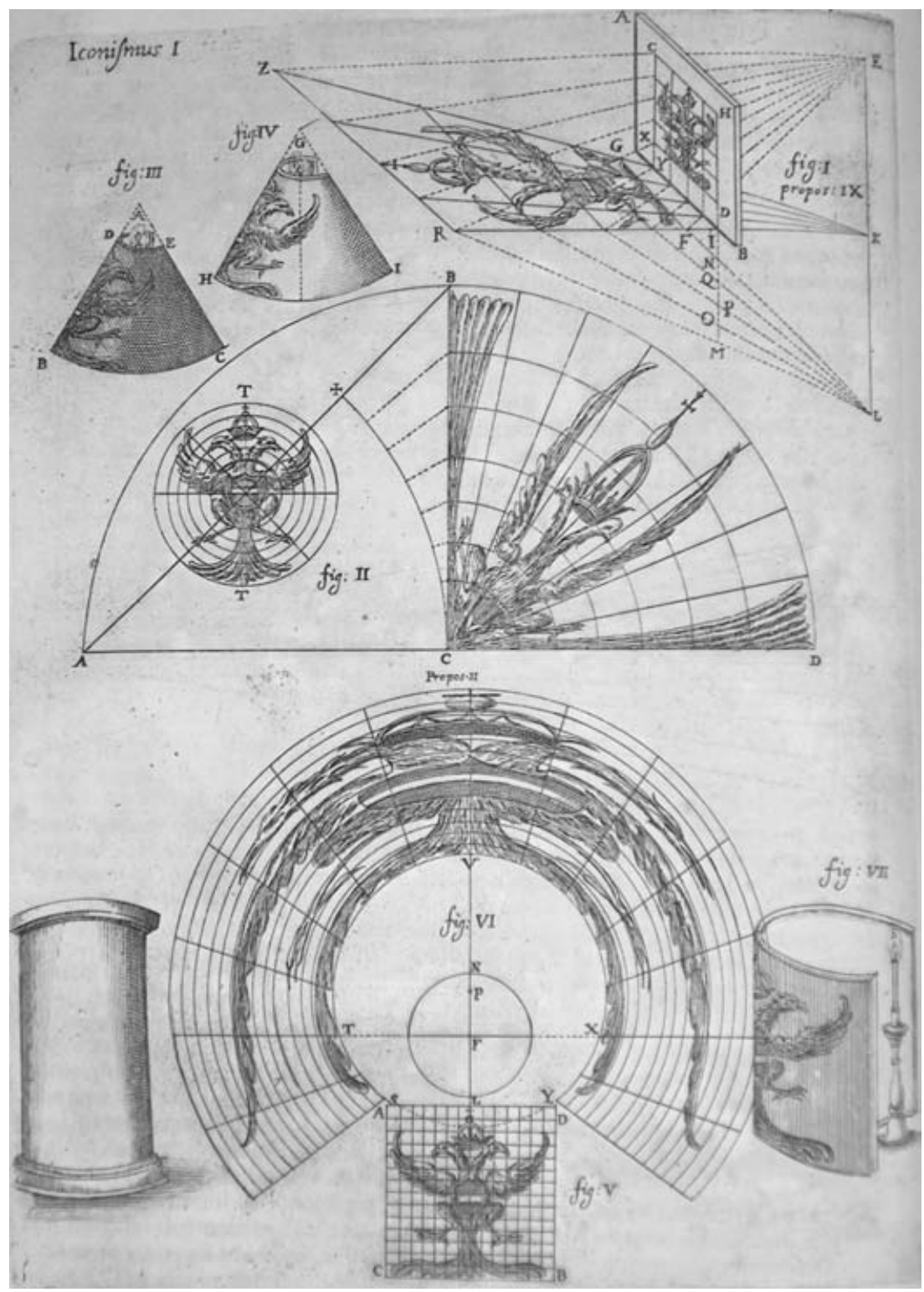

Figure 11. Kircher's conical and cylindrical anamorphoses, depicting a Habsburg eagle, in A. Kircher, Ars Magna Lucis et Umbrae, Amsterdam, 1671, 134 (184 in the 1646 edition). The metaphysics of light explains why an obsolete and ineffective technique for making an anamorphosis is still depicted. One places a light behind a cylindrical screen which is punctured in the form of an eagle. A deformed outline of the eagle will appear on the page and one can draw the anamorphosis in this way. This technique proves to be almost unworkable in practice, but it shows clearly the metaphysical principle that the light $(l u x)$ is deformed by an intermediary (a lens or a mirror; in this case a punctured screen) and creates the chaotic images of the world. The undistorted image (angelic message) can be retrieved by using special ('religious') knowledge (a conical or cylindrical mirror). Courtesy of the Library of Theology, Leuven University. 


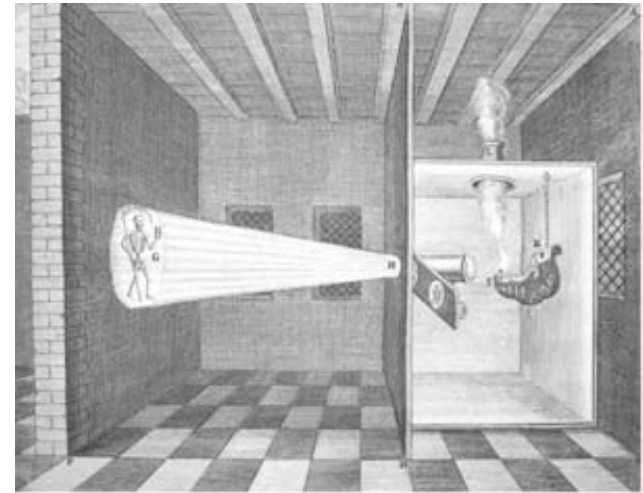

(a)

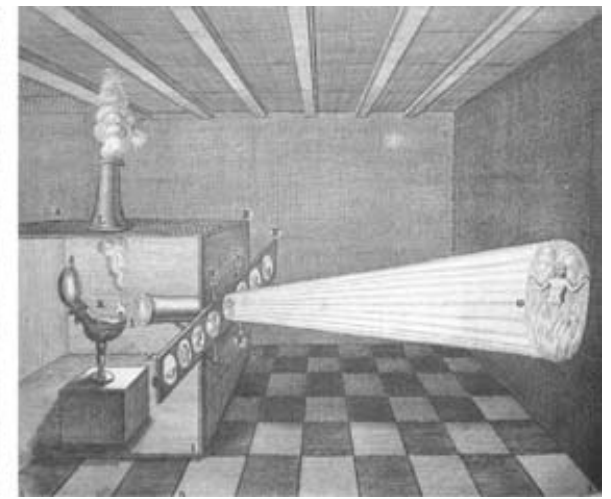

(b)

Figures 12a and b. Kircher's famous drawings of the magic lantern, inserted in the section 'Magia Catoptrica' of the 1671 edition of the Ars Magna. A. Kircher, Ars Magna Lucis et Umbrae, Amsterdam, 1671, 768-9 (not in the 1646 edition). These figures were long thought to be the first drawings of the instrument and Kircher was credited with its invention. It can be clearly seen (in comparison with Figure 1 above) that the tube is constructed on the wrong side of the lantern slide. This 'mistake' makes the device in fact a point light-source projection system instead of a magic lantern. But there were metaphysical reasons for constructing the projecting mechanism in this particular way. Courtesy of the Library of Theology, Leuven University.

times (this is the ratio for point light-source projection and can be contrasted with magnifications achieved by other contemporary magic lanterns; cf. Figure 4). ${ }^{48}$

Figures $12 \mathrm{a}$ and $12 \mathrm{~b}$ correspond to the description in Kircher's text, where the narrative follows the structure of the instrument in the correct order. The description starts with the lamp $\mathrm{K}$ and the stand $\mathrm{M}$, and continues with the lens at the beginning of the tube $(\mathrm{I})$, the painted slide at the end of the tube $(\mathrm{H})$, and the projected image on the wall. ${ }^{49}$ Notwithstanding this clear description, Kircher was aware that another

48 Nonetheless, W. A. Wagenaar has argued in his paper (op. cit. (7)) that it was the engraver who inserted the wrong images. According to him, Kircher's 'correct' sketches were probably lost between Rome and Amsterdam, so that the engraver had to work with the description of the instrument in the text. In order to save Kircher from making an 'error' and to affirm that Kircher described the 'correct' magic lantern, Wagenaar misconstrues Kircher's text as a function of his argument. He tries to establish that Kircher's description was ambiguous with respect to the placing of the tube (which it is not, because it is clearly a description from one side of the instrument to the other) and does not mention passages like that quoted here in note 50 below. Wagenaar used his discovery that the pictures correspond to a real experimental setting not to challenge the view that the pictures were erroneous but to make plausible his claim that it was the engraver who inserted these particular 'wrong' pictures. According to Wagenaar, this engraver did not trust his own reading (Wagenaar's reading) of Kircher's text for one reason or another, and verified his interpretation experimentally without verifying the other possible interpretations. After some experimenting, Wagenaar suggests, this engraver discovered a plausible point light-source projection, which he drew and inserted in Kircher's text. When we give up the idea of erroneous figures, however, we do not have to construct a detective story about lost and 'wrong' pictures, for which there is no evidence. Nor do we have to imagine engravers experimenting with optical set-ups expensive and sophisticated for the time.

49 Kircher, op. cit. (4), 769: 'Make a wooden box A.B.C.D, with a chimney at L, so that the lamp can emit its smoke through it; put the Lamp K itself in the middle of the box, either suspended by a metal wire or placed on a stand $\mathrm{M}$, opposite to an aperture $\mathrm{H}$, in which a high-quality tube is mounted; and in the beginning I of the 
composition was also possible, since he wrote that 'the tube may point either inwards or outwards' ${ }^{50}$ Kircher clearly favoured the design he depicted in Figures $12 \mathrm{a}$ and $12 \mathrm{~b}$, since he described this design in his text and, furthermore, he wrote that his pictures would explain the instrument better than his words. ${ }^{51}$ In this case the pictures have the primacy. Kircher's judgement might have prompted him to choose a design of the magic lantern which conformed to his metaphysics, as I will now show. ${ }^{52}$

Just like his devices for mirror projecting and making metamorphoses, the magic lantern can be interpreted metaphysically. In the magic lantern, light (lux/God) is diffracted by the first clear and bright lens (angel), then again even more dispersed by a second but opaque lens (man), casting shadows possessing form and figure (knowledge/

tube, mount a lens of a superior brand; in the aperture or the end of the tube H, place a well-polished flat glass, on which you can paint whatever you want with transparent watercolours. In this way, the light from the lamp, as it passes through the glass lens, will exhibit the picture painted on the glass plate $\mathrm{H}$ (which has to be drawn in a reversed position on the glass) on a white wall VTSX, in correct position and enlarged, with all the colours as drawn from life.' ('Fiat ex ligno receptaculum A.B.C.D. deinde in L caminus, ut Lucerna per illum fumum suum emittere possit, Lucerna vero $K$ in medio ponatur vel affixa filo ferreo vel supra fulcrum $M e$ regione foraminis $H$, intra quod tubus palmaris committatur, in tubi vero principio I. lenticulare vitrum melioris notae inferatur[;] in foramine vero, seu in fine tubi H vitrum planum probe elaboratum ponatur, in quo coloribus aqueis \& diaphanis quidquid volueris pingatur; hoc pacto intra cubiculum VTSX in muro candido lumen lucernae vitrum lenticulare transiens imaginem in H vitro plano depictam (quae inverso situ in vitro ponitur) rectam \& in muro grandiorem exhibebit, omnibus coloribus ad vivum expressam.') This description fits well with Figures $12 \mathrm{a}$ and $12 \mathrm{~b}$. The bracketed passage 'quae inverso situ in vitro ponitur' could also be translated as 'which has to be put upside down on the glass'. But Figures 12a and 12b show upright pictures on the slide, which is correct, since Kircher's figures depict a point light-source projection. Therefore I interpret this sentence as: 'which has to be drawn in a reversed position on the glass'. If Kircher really meant ' upside down' instead of 'reversed', he could have referred after all to a Huygens-type magic lantern (with the tube on the outside, see Figure 1), since in such a magic lantern the slides have to be inserted upside down. Kircher indeed considered both designs and he wrote that one must judge for oneself which was the best (cf. note 50 below). The possibility of two different designs may explain some confusion in the text.

50 Kircher, op. cit. (4), 770: 'Nota hoc loco tubulum vel intra vergere posse vel extra, perinde est sed haec judicio boni praedici relinquenda sunt.'

51 Kircher, op. cit. (4), 770: 'Sed haec sat dilucide exposita esse existimo, quare nil restat, nisi ut consectarium ex dictis resultans sequenti figura II pariter explicemus', and 'Sed haec omnia ex praesenti figura II melius intelliges, quam ego pluribus verbis non explicavero'.

52 There is another possible reason for preferring his design. As we saw, the difference between the two designs of the magic lantern is that Kircher's preferred version does not enlarge as much as Huygens's or 'sGravesande's lantern. In fact, Kircher was more interested in a projection process that did not enlarge the image, because he tried to transmit pictures over a long distance while keeping their size within limits, as we can see in his description of his device for 'mirror projecting' (Figure 7). He wrote, 'The only problem is that the images are enlarged into infinity; e.g. one single letter seems to grow into a tower.... Thus if someone finds out a method by which he can reduce pictures of things at a large distance to a smaller proportion, and also make them appear with enough clarity, then he will indeed have found out a secret to be proud of.' Kircher, op. cit. (4), 793. ('Solum incommodum illud intervenit, quod species rerum in immensum auctae [?], verbi gratia una litera, successive in turrim crescere videatur. ... Si igitur quis invenerit modum, quo figuras rerum in maxima distantia in minorem proportionem redigat, clareque exhibeat; arcanum, quo gloriari possit, se invenisse laetabitur.')

Kircher's figures of the magic lantern are not erroneous. They depict his choice between two possible designs for projecting images in a dark space by means of candlelight. In Kircher's view, it was even an advantage that his magic lantern did not enlarge the image too much. Furthermore, this design was favoured because it conforms to his metaphysical principles, the structure of which permeates his whole work. On the relation between Kircher's artefacts and his metaphysics see my forthcoming paper, op. cit. (33). 
world). Here the metaphysical symbolism can explain the alleged mistake in Kircher's engraving of the magic lantern (Figures $12 \mathrm{a}$ and $12 \mathrm{~b}$ ), which has caused so much bewilderment in modern readers, since the metaphysics dictates that the bright lens (angel) should be closer to the light source than the painted lens or slide (man). ${ }^{53}$ This symbolism becomes even more evident and pervasive if one sees in the projected shadows the shadow theatre of Plato's cave. ${ }^{54}$ By combining instruments and metaphysics, Kircher visualizes invisible philosophical truths about the universe. ${ }^{55}$

\section{Vallemont and analogical demonstration}

I now shift to a different context, to the Paris and Versailles of the reign of Louis XIV. I focus on a description of the magic lantern in the work of Pierre le Lorrain, Abbé de Vallemont (1649-1721). Vallemont was a theologian who worked as a private teacher and was employed in Paris by Pollart, a counsellor of the parlement, and in Versailles, by the Marquis de Dangeau, a favourite of Louis XIV. Vallemont read all the new scientific works, collected curiosities, explored the gardens of Versailles and often visited the collections of the king. He wrote popular works on physics, gardening and numismatics and was always engaged in contemporary disputes. He mentioned the

53 My interpretation is in line with Hankins and Silverman's (op. cit. (2), 15-33) interpretation of Kircher's sunflower clock. The sunflower clock was a newly invented clock, described by Kircher, allegedly driven by the magnetic power of the sun on a sunflower. Hankins and Silverman show that this clock failed the tests of contemporaries and argued that it was unworkable as an instrument or experiment, but instead demonstrated the hidden divine powers in the cosmos that are expressed in magnetism. I argue that the magic lantern was likewise a symbol of occult powers. What is more, there is in Kircher's texts a connection between the ubiquitous occult and cosmic power of magnets and light. Indeed, both the Magnes and the Ars Magna give a general world view, but from a different perspective (or thole-pin): in the Magnes it is the occult magnetic power which rules the world; in the Ars Magna it is light. Kircher makes this link explicitly: the Ars Magna is an ars 'magna' in reference to the 'magnet' (Kircher, op. cit. (4), preface: 'Magnam dicimus, ob occultam quandam ad Magnetem allusionem.') and 'light is the number and measure of everything, the celestial magnet-stone, drawing everything to itself.' (Kircher, op. cit. (4), 2: 'Omnium rerum \& numerus est, \& mensura, Magnes coelestis omnia ad se trahens.') Both magnet and light are interchangeable symbols for divine workings and emanations, and these symbols are displayed in the Baroque rhetoric of Kircher's theatre. On the relation between Kircher's philosophy of light and his philosophy of magnetism, and for a critical discussion of Hankins and Silverman's views, see my forthcoming paper, op. cit (33).

54 See note 37 above. If we take this explanation a little further, we can explain why monsters and demons were a recurrent theme. The projected lantern slides in Kircher's engravings show the iconic personification of Death (Figure 12a) and a man burning in Hell (Figure 12b). If the original light source symbolizes God, if the lens and the slide symbolize an angel and man respectively, the image projected on the screen is furthest away from God, and properly depicts and symbolizes Death, demons and Hell. This might be a step too far, however, because of Kircher's Neoplatonism. In Christian theology, the demons are furthest away from God, but in Neoplatonic philosophy, there is no distinction between angels and devils, and all 'daemons' are superior spiritual beings located higher than man in the scale of being. The proper place of demons is one of the thorny problems in every combination of Christianity and Neoplatonism. Kircher's metaphysics is flexible enough, however, and contains enough ambiguities to make it possible to fit in most natural and artificial objects.

55 This makes clear that Kircher's use of his instruments is not trivial. The use of the artefact has to be interpreted with regard to its context, and we should not discard metaphysical and other uses. From a metaphysical point of view Kircher's instrument would definitely function better than the other version of the magic lantern. 
magic lantern in his popular book La Physique occulte (1693), ${ }^{56}$ where it appears in the context of a physical discussion of the nature of light.

Vallemont is a (pseudo-)Cartesian atomist, ${ }^{57}$ and he describes light as rays of subtle particles. This makes it surprising that light particles are not dispersed by wind, and that different light rays can pass together through the same point without affecting each other. The rays do not mingle and their forms and colours are preserved. In order to demonstrate this, Vallemont invokes the magic lantern and sets out how it is constructed, thereby explaining that the rays or traces of particles become one and penetrate each other in the tube of the lantern because of the lenses. Yet the rays keep their direction and draw 'the phantom of the object with all its colours' on the screen. ${ }^{58}$ The use of instruments to demonstrate physical principles was already common in the Cartesian circles of Paris. From the 1660s, Jacques Rohault staged the wonders of nature in an elaborate play. ${ }^{59} \mathrm{He}$ demonstrated numerous phenomena with his wide assortment of instruments and provided them with Cartesian explanations. Vallemont referred to the authority of Rohault's demonstration lectures and he used the latest curiosity in a similar vein - to demonstrate a physical phenomenon in a Cartesian setting. ${ }^{60}$

But Vallemont did more, and this becomes clear if we recognize that his demonstration of the behaviour of light rays is a key moment in an argument on the physical explanation of dowsing. La Physique occulte was written in the context of a debate on the divining rod, evoked by a spectacular case of dowsing at the time. ${ }^{61}$ Vallemont denied any demonic intervention in dowsing and set out to explain the phenomenon by means of very subtle particles. Water sources, gold and even murderers could be found by the specific kind of vapours they exhaled, and the divining rod worked 'like a microscope', enlarging the effect of those vapours on man. When tracing murderers, the

56 I have found editions in Paris $(1693,1696,1707,1709)$, Amsterdam $(1693,1696)$ and The Hague $(1722$, 1747), and a German translation (Nuremberg 1694), an unacknowledged plagiarism (Bamberg 1756) and even later editions in 1752 and 1762.

$57 \mathrm{He}$ wants to ally himself with the Cartesians, but he regards the differences between Gassendi and Descartes unimportant. His use of astrology, for instance, makes his work an awkward blend.

58 Vallemont, op. cit. (25), 400: 'Le fantôme de l'objet avec toutes ses couleurs.' He illustrates this also with more established demonstrations of this phenomenon (cf. Alhazen, see A. C. Crombie, Science, Optics and Music in Medieval and Early Modern Thought, London, 1990, 191).

59 See G. V. Sutton, Science for a Polite Society: Gender, Culture, and the Demonstration of Enlightenment, Oxford, 1995, 107; and T. McClaughlin, 'Descartes, experiments, and a first generation Cartesian, Jaques Rohault', in Descartes’ Natural Philosophy (ed. S. Gaukroger, J. Schuster and J. Sutton), London, 2000, 330-46.

60 Vallemont, op. cit. (25), 401: 'Au defaut d'oeil artificiel dont M. Rohaut enseigne la construction, je vais donner isy la Lanterne magique, qui est admirable pour demonstrer'. See also J. Rohault, Traité de physique, Paris, 1671, 328.

61 E.g. Journal des sçavans, 12 January 1693, 27 April 1693; see also K. Vermeir, "The "physical prophet" and the powers of the imagination, part II: a case-study on dowsing and the naturalization of the moral (1685-1710)', Studies in History and Philosophy of Science (2005), 36C (1), 1-24. A peasant had discovered murderers with a divining rod; for the episode and performed experiments see M. R. Lynn, 'Divining the Enlightenment: public opinion and popular science in old regime France', Isis (2001), 92, 34-54. Other cases of dowsing were well attested by reputable witnesses, experiments were performed and even Boyle had shown interest. 
diviner followed a stable track that remained unaltered for several hours. Vallemont had to demonstrate that the subtle particles were not mixed and blown away by the wind. He argued that those particles were so subtle that they did not interact with the coarser air particles, and that the whole world was filled with subtle particles which did not modify each other. This explanation would have been very dubious if Vallemont had not been able to demonstrate that there existed particles with exactly such a behaviour.

It is precisely this that the magic lantern had to demonstrate: light particles behaved like the occult particles Vallemont envisioned. The wind did not blow away the subtle transpirations exhaled by the murderers, just as the wind did not blow away the light rays and the luminous image projected by a magic lantern. Even if different people came together at one place and separated again, their specific transpirations would not mix and lose their distinctiveness. That is why the divining rod would still be able to trace these people separately, just as the different colours of the lantern image are not modified even if the light rays go through one single point somewhere in the tube of the magic lantern. This makes it clear that the magic lantern was not only used as a metaphor for the eye and as a demonstration of a physical principle. It was also an 'analogical demonstration' of the properties of occult or invisible particles. Vallemont proved that his explanation of dowsing was probable by arguing that there were similar phenomena which really could be demonstrated. As in Kircher's case, the magic lantern serves to make the invisible visible.

The world is full of occult (imperceptible or hidden) powers such as magnetism, electricity or even light, ${ }^{62}$ and only the effects of these occult powers are visible. Cartesians explained these phenomena by introducing subtle particles with certain forms. ${ }^{63}$ To convince the reader, they often invoked analogical models, to make it easier to conceive the hidden workings of nature. These analogies were relatively easy to construct and appealed to the public imagination. Cartesianism became a game in itself when it was adapted by court and salon culture. ${ }^{64}$ It was a game for the diversion of the gentry with sophisticated and alluring analogies and explanations of natural phenomena. Vallemont combined this trend for analogical reasoning with the fashion for demonstration lectures in a specific way. By demonstrating a known principle of light and by using an analogy between light and subtle transpirations, he achieved something very different from other demonstrators and Cartesians.

An analogical demonstration is used in a similar way as an experiment, to create new knowledge. In experimental science, heuristic analogies are usually tested in experiments upon the real thing. If proved valid, the analogy might be used in demonstrations to elucidate the tested and known principle. ${ }^{65}$ Vallemont, however, employs an

62 See note 38 above.

$63 \mathrm{~K}$. Hutchison, 'What happened to occult qualities in the scientific revolution?', Isis (1982), 73, 233-53. 64 Sutton, op. cit. (59).

65 Newton, for instance, made an analogy between light and sound which guided his research into the nature of light and incited him to formulate new hypotheses. To confirm these hypotheses, he of course did not demonstrate experiments with sound. He tested his hypotheses and scrutinized his analogy by doing experiments on light or by reconsidering the evidence, and if necessary, adjusted and rephrased his original analogy when the evidence compelled him (e.g. in a 1675 letter to Oldenburg, the correspondences between light and 
analogical demonstration, based on an unquestioned analogy, to generate new knowledge of the interactions of invisible and unknown vapours. By introducing the magic lantern at a crucial phase of his argument, Vallemont succeeded in visualizing his theory in a convincing way, drawing upon the growing authority of experimental philosophy and on the fashion for demonstration lectures. By means of an analogical demonstration he in fact demonstrates the indemonstrable. By analogy he transforms his occult particles into light particles and by means of the magic lantern he makes those invisible light particles visible. That is, in the luminous projected image one can clearly see that the colours are not mixed up or blown away.

\section{Illusionist and demonstrative metaphysics}

The magic lantern embodied different notions of 'illusion'. As a projection device, creating strange apparitions, it was seen as akin to devilish delusions. As a technical wonder, it could be seen as a trick, an allusion or an illusion (a real illusio as a rhetorical figure). These kinds of 'illusion' are of course not independent. For example, the trick and the rhetorical illusio can here draw in part on the unmasking of the devilish illusion for their effect. ${ }^{66}$ Vallemont writes, 'The magic lantern is an Optical machine, \& which one calls Magical, without doubt because of its prodigious effects, \& the ghosts, \& the frightening monsters that it shows, $\&$ which is attributed to magic by people who do not know the secret. ${ }^{\prime 67}$ In this play of unmasking, the theologian coincides with the magician; both claim access to what is hidden and its associated power.

Delusion and allusion, however, were rhetorically drawn apart, reinforced and came to stand for different social milieux. Gaspar Schott (1608-66), Kircher's disciple and editor, defined magic as 'whatever is marvellous and goes beyond the sense and comprehension of the common man'. ${ }^{68}$ The common man was prone to superstition. Only the educated gentry were able to enjoy the play and read the hidden messages. This helped constitute a distinct elite culture. Marvellous devices were referred to the incapacity of the vulgar. ${ }^{69}$ This rhetoric was also a vehicle of the CounterReformation to combat popular magic, which became identified with superstition, in contrast with the learned magic on which Catholic theology depended. Kircher

sound are different from those in his 1672 letter). For matters of presentation, he could of course use his analogy again. All this did not stop Newton sometimes being misguided in his judgement because of this analogy, as when he divided the spectrum of light from a prism into seven component colours similar to the notes in an octave. See J. North, 'Science and analogy', in On Scientific Discovery (ed. M. D. Grmek, R. S. Cohen and G. Cimino), Dordrecht, 1980, 115-40. On experiment, demonstration and analogy see also W. D. Hackmann, 'Scientific instruments: models of brass and aids to discovery', in The Uses of Experiment: Studies in the Natural Sciences (ed. D. Gooding, T. Pinch and S. Schaffer), Cambridge, 1989, 31-65.

66 This is typical in natural magic. I cannot show the different interactions in this essay. One, of course, is that associations with the devilish stayed present in a harmless but exciting way. See also note 72 below.

67 Vallemont, op. cit. (25), 402: 'La lanterne magique est une machine d'Optique, \& que l'on nomme Magique, sans doute à cause de ses effets prodigieux, \& des spectres, \& monstres affreux qu'elle fait voir, \& que les personnes qui n'en savent pas le secret, attribüent à la magie.'

68 See Gorman, op. cit. (26), 19; for similar remarks see Vallemont, op. cit (25), 64-5.

69 See Gorman, op. cit. (26), 9-14; and P. Burke, Popular Culture in Early Modern Europe, London, 1987. 
provided his patrons, the Catholic intelligentsia, with such an elitist magical and metaphysical system. ${ }^{70}$

Both Kircher and Vallemont tried to prove their orthodoxy as theologians. ${ }^{71}$ They did not deny the existence of demons and magicians, since they knew that these were essential for Catholic theology. But they explained that encounters with them were very rare. Kircher ridiculed those who did not see the natural causes behind his illusionist devices. He also denounced those ancient priests and kings who claimed to possess supernatural powers and who used their technological knowledge for the oppression of their people. But denying the action of demons in pagan belief and explaining everything naturally could easily be turned into a dismissal of the supernatural in Catholicism as well. To forestall this danger, Kircher had to perform a balancing act. He had to affirm that the involvement of demons was still possible. ${ }^{72}$ Notwithstanding his assertion that dowsing was a purely natural phenomenon, Vallemont also rejected van Dale's statement that apparitions in biblical antiquity were in fact optical projections made by magic lanterns, in this way sustaining Biblical truth. ${ }^{73}$ By explaining occult phenomena in a natural (Cartesian) way, he remained religiously orthodox and used the same rhetoric as the Jesuits. ${ }^{74}$ By showing that occult phenomena pervaded the world, he retained the magical world view that Christianity needed, a world view based on the invisible beneath the visible. ${ }^{75}$ With his demonstration of the magic lantern, and his attempts to visualize the hidden, he showed that in special cases the invisible could become visible. ${ }^{76}$

Courtly culture and Catholic faith were closely intertwined at the time of Louis XIV. The absolutist Sun King based his power on a combination of worldly and godly

70 For the use of the term 'magic' in the context of Catholicism see Evans, op. cit. (5), 115-16, Chapters 10 and 11; see also his discussion of Kircher's Oedipus Aegyptiacus, ibid., 435-42.

71 Notwithstanding Vallemont's efforts, La Physique occulte was condemned by the Church, but not for theological or metaphysical reasons, rather for moral issues concerning the kind of evidence in the prosecution of murderers. Kircher had also been accused of propounding heretical ideas by M. Corneus, a fellow Jesuit.

72 Kircher, op. cit. (4), 784. I think this solves Gorman's puzzlement about Kircher's commitment to demons in his exposure of the fraudulence of Egyptian priests (Gorman, op. cit. (26), 8). See also Kircher, op. cit. (4), 780: 'Pessimum inter alia est \& illud, quod apparitiones spectrorum, non permissioni divinae; sed hominum catoptricis experimentis aliis illudentium sagacitati adscribat: in quo Atheis hujus temporis adstipulari videtur, qui ut omnes non sacrae tantum, sed \& prophanae historiae apparitiones una cum Deo, totaque religione aboleant, eas naturae viribus, \& ab hominibus sagacibus, \& philosophis impostoribus processisse affirmant.' (The worst is also this, that he [Riesler] does not attribute the apparitions of spectres to the Divine consent, but to the cleverness of the people who show illusions to others by means of catoptrical experiments. In this, he seems to resemble all the atheists of this age, who, in order to abolish the apparitions of not only the sacred but also the profane history together with God and the whole religion, maintain that these apparitions are caused by the powers of nature and by ingenious people and philosophers-impostors.)

73 See Vallemont, op. cit. (25), 400 ff. and 552-6. See also van Dale, op. cit. (41), Fontenelle, op. cit. (41).

74 Cartesianism was not forbidden, but Cartesians had to refrain from explaining transubstantiation. R. A. Watson, 'Transubstantiation among the Cartesians', in Problems of Cartesianism (ed. T. Lennon, J. Nicholas and J. Davis), Kingston, 1982, 127-48.

75 Astrology was also an essential part of his explanation. For the use of the term 'magic', see note 70 below.

76 In this way, he provided a subtle metaphorical support of the praesentia realis and the incarnation; one might even say that the magic lantern served as a kind of monstrance, as a demonstration (monstrare) of the Catholic faith. 
legitimation. A play of symbols and allusions mirrored this pact. In natural philosophy and natural history, such a play of allusions could also be found. Astrology was sometimes kept alive partly because of its usefulness in pleasing powerful rulers. As a courtly diversion, exotic objects and strange animals were imported, examined and even dissected by the précieux for the amazement of their peers. The chameleon, for instance, was studied and its aptitude for false appearances was widely discussed. The précieux even attached moral lessons to their findings, comparing chameleons with courtiers. ${ }^{77}$ One of these courtiers, Vallemont, framed his world view of occult interactions in the fashionable concepts of Cartesian vortices and collisions. The French court was under the spell of the marvellous just as much as other courts of Europe, but it added a peculiar play to this by using Cartesianism as the flexible framework with which to explain the wondrous. As Vallemont writes, Cartesianism is the best theory with which to explain the marvels of nature.

The different kinds of 'illusion', however, refer not only to different social milieux; they are also conceptually distinct. The first - the delusion - presupposes that one surrenders to the image and loses oneself in the delusion. The second - the allusion - draws on a suspension of belief, a critical distance, a recognition of the joke as joke. But often a joke is not just a joke, and one has the feeling of something really elusive, alluding to a deeper meaning. Only this third step really fulfils the possibilities of the rhetorical illusio. ${ }^{78}$ It is here that what I have called 'analogical demonstration' fits. ${ }^{79}$ This is not a demonstration in the sense of a mathematical proof, nor is it a direct experimental demonstration of a physical principle like the demonstrations of the anatomist, or the demonstration lecture. ${ }^{80}$ One can interpret it as a curious blend between the a-priori thought typical of rationalism and the experimental culture of empiricism. An analogical demonstration is a magical symbol visualizing invisible and hidden processes in nature. ${ }^{81}$

In the late seventeenth century there was a complex interaction between practices, theories and instruments, strongly dependent on the context. Instruments and demonstrations could be applied in different ways, and Rohault's demonstration lectures were a model both for 'sGravesande's mainstream and Vallemont's analogical

77 Sutton, op. cit. (59), 124. It is instructive to compare the role of the chameleon with that of the magic lantern.

78 We might speak of three kinds of illusion: first, the delusion; second, the joke or allusion; and third, the elusive illusion, which is akin to the mannerist 'serious joke'. But the last two are similar in that they presuppose a critical distance; they get the joke. This distance is characteristic for playing; see J. Huizinga, Homo ludens, Proeve eener bepaling van het spel-element der cultuur, Haarlem, 1951.

79 The hidden analogies represent the elusive aspect, while the demonstration corresponds to the performative aspect of the illusio.

80 The argument of my paper should be read in relation to Hankins and Silverman's (op. cit. (2)) account of the different kinds of demonstration.

81 An analogical demonstration can be defined as a physical (instead of mathematical) demonstration of something invisible, something indemonstrable in a direct way. This indemonstrable quaesitum is visualized by means of an instrument, relying on an a-priori analogy between the quaesitum and a demonstrable datum. Vallemont (op. cit. (25), 143) is positive about the force of his demonstrations: 'J'espère mettre toutes ces choses dans une telle évidence, qu'elles passeront, pour être exactement démonstrées chez ceux qui savent ce que c'est que démonstration en matière de Physique.' 
demonstrations. Instruments could shift from magical contexts to natural philosophy, and sometimes the borderlines are far from clear. Analogical demonstrations can be found in the work of both Cartesian and Jesuit authors with some interest in the occult. Kircher's instruments mirrored the hidden Neoplatonic structures of the universe. They were analogical demonstrations of undemonstrable philosophical principles. In a similar way, Vallemont's magic lantern visualized by analogy the invisible particles that moved the dowsing rod..$^{82}$ Both cases make clear that experimental, metaphysical and theatrical demonstrations cannot be clearly separated. ${ }^{83}$

\section{Conclusion}

The magic lantern was a specific example of an analogical demonstration and an illusio peculiar to Baroque rhetoric. In both Kircher's and Vallemont's work text, illustration and display interact in a complex and specific way to form such an analogical demonstration. It shows and explains at the same time, just like a symbol or emblem. ${ }^{84}$ Both these aspects are necessary to grasp the truth, a philosophical truth, defended by a blend of an idiosyncratic empiricism that compels them to demonstrate the order of nature

82 Of course, notwithstanding the striking similarities, Kircher's demonstrations are not of exactly the same kind as Vallemont's. First of all, they propound radically different philosophical systems. Furthermore, in Kircher's case, the (structure of) the instrument itself is the demonstration, which makes it possible to interpret the instrument as a reification of a metaphysical principle, while in Vallemont's demonstration the magic lantern demonstrates and visualizes a physical principle which is thought to be analogous with the quaesitum.

83 It should be noted, however, that Vallemont's analogies are not totally different from the analogies Descartes used in order to 'visualize the invisible' (or from other uses of analogy in natural philosophy and science), and his demonstrations are not completely alien to the scale models of von Guericke, Cavendish and others, making this conclusion more general than was to be expected. Furthermore, the demonstrations of experiments performed at the Royal Society had theatrical and metaphysical aspects too. Notwithstanding the differences in style in art and science between southern and northern or Catholic and Protestant countries, a comparative study between modes of representation and demonstration in Rome, Prague, Paris, Leiden and London, for instance, which takes theatrical and metaphysical aspects into account, would be particularly significant. For the difference between southern and northern styles see e.g. S. Alpers, The Art of Describing: Dutch Art in the Seventeenth Century, Chicago, 1983. For Descartes's analogies see P. Galison, 'Descartes's comparisons: from the invisible to the visible', Isis (1984), 75, 311-26. For scale models see Hackmann, op. cit. (65). On analogy in science see North, op. cit. (65); and M. Hesse, Models and Analogies in Science, Notre Dame, 1966.

84 Kircher's magic lantern is not an emblem in the strict sense, however. The use of symbols and emblems was an important point of debate in the seventeenth century, in which Kircher and his fellow Jesuits played an important role. Kircher's definition of a symbol is better applicable to his use of the magic lantern: 'Strictly speaking the Greeks called "symbol" a visible sign of hidden circumstances; which the Latins explained in these terms: a symbol is a significant mark of some arcane mystery; i.e. the nature of a symbol is to conduct our soul, by means of some likeness or another, to the understanding of some thing which differs much from the things which are presented to the external senses; it has the property of being concealed and hidden under

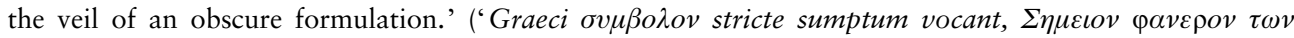
$\pi \rho \alpha \gamma \mu \alpha \tau \omega \nu \alpha \varphi \alpha v \omega v$; quod Latini explicant his verbis: Symbolum est nota alicuius arcanioris mysterii significativa. Id est, natura Symboli est, conducere animum nostrum mediante certa aliqua similitudine ad intelligentiam alicuius rei multum a rebus, quae sensibus offerentur exterioribus, differentis; cuius proprietas est esse coelatum \& absconditum sub velo obscuri dicti.') A. Kircher, Oedipus Aegyptiacus, 3 tomes in 4 vols., Rome, 1652-4, ii.1, 6; see Evans, op. cit. (5), 437. 
(showing) and a doctrinal religiosity that invariably underpins their argument (explaining). Their rhetoric is not merely textual. Its characteristic feature is to be found in the interplay of textual, visual and performative rhetoric.

Kircher's Ars Magna is not just an encyclopaedia or a list of instruments. In his work texts and instruments are intrinsically connected, and the metaphysical preface and epilogue are crucial for the interpretation of the pictures and descriptions of the instruments in the rest of the book. The instruments, on the other hand, are the necessary test or incarnation of his metaphysical principles. Texts and instruments are mutually indispensable for Kircher's work, which aimed at the visualization of the invisible. On the one hand, the instruments must be read as a rhetorical text, and they embody contemporary rhetorical figures such as the inventio, illusio and allusio. On the other hand, while the instruments were shown in the Collegio Romano, the text, the Ars Magna itself, must be seen as a performance as well.

Placing the magic lantern in its Baroque context, it should be stressed that it was not merely shown but was performed. The displaying of instruments was not like a demonstration lecture, but resembled a Baroque Jesuit show or theatre, which hints in an indirect way to what is really demonstrated: not a known physical law, but an invisible world, the existence of which is postulated on the basis of fixed metaphysical principles. By using this kind of demonstration, Kircher and Vallemont adapted their style to the cultural milieu very well. They tried to constitute a real Christian science. With the sensitivity of a showman or performer, both gave a new kind of defence to their philosophy and religious world view.

In this article, I have tried to show new ways in which the relation between instruments and the occult might be conceptualized. Neither rationalist philosophy nor experimental practice was necessarily hostile to occult philosophy. Besides the long tradition of mathematical magic, ${ }^{85}$ there might have been other kinds of instrumental magic. Instruments might have had hidden meanings never envisioned by us. I have explored the case of the magic lantern, which was perceived to be magical for many reasons. There were associations with demonic apparitions conjured up by necromancers. The magic of the stage was present, too, with the illusionism and tricks of a good performance. Many inventors of projection machines stressed the possibilities for deceiving the superstitious. ${ }^{86}$ By employing the concepts of illudere, alludere and eludere, however, I have shown that the magic lantern was principally magical because it was an 'analogical demonstration' of a magical universe, permeated by occult and marvellous phenomena. In doing this, I have suggested that the magic lantern, in its creation of illusionary images, embodied a counter-model to the way of objectivity and truthfulness which science eventually claimed to follow.

85 This is the branch of magic which was engaged in the invention and use of instruments and mechanical devices. The pyramids, speaking statues and hydraulic pumps were all attributed to mathematical magic.

86 E.g. G. Della Porta, Natural Magick, London, 1658, XVII.vi; See also Hooke, op. cit. (4), 741: 'had the Heathen Priests of old been acquainted with it, their Oracles and Temples would have been much more famous for the Miracles of their Imaginary Deities. For by such an Art as this, what could they not have represented in their Temples? Apparitions of Angels, or Devils, Inscriptions and Oracles on Walls' (original emphasis); see also Mannoni, op. cit. (1), 53. 
The specific Baroque culture in which this practice was embedded went into decline in the eighteenth century. The wondrous, the plays of knowledge and the plays of nature, were moved from the scene of science to the pages of fiction. ${ }^{87}$ Illusion, too, became defined in another way; it lost its meaning as rhetorical play and dispelled the wondrous. Vraisemblance or truthfulness became a condition for illusion as well as for truth, starting a new dynamic. This coincided with a new attitude towards the image in theatre, painting and science, ${ }^{88}$ providing a counter-movement to the Catholic Baroque. Illusion lost much of its demonic and ludic characteristics. The meaning of 'superstitious' changed from dangerous and false to silly, powerless and vulgar, ${ }^{89}$ and images, plays and demonstrations lost their power to allude to something beyond. Illusion did not show an invisible world any more, but became the semblance of the visible. The concept of likeness changed 'from aletheia to adequatio, from appearing to seeming, from dissimulation to simulation, from appearance to replica'.$^{90}$ Truth and illusion came together at the surface of the phenomena and became two sides of the same coin. In this context, the monsters of the lantern could not be enjoyed any more by the cultural elite, and were transferred to a new public. In the eighteenth century the lantern was shown by savoyards and luikerwalen, the poorest of people, to entertain the lowest classes. Only such people were now considered credulous and superstitious enough to suspend their judgement so as to be able to enjoy the show. But the magic of the lantern was not yet fully defeated. It took until the nineteenth century before its images could represent truth, and before it became used in scientific and religious propaganda. ${ }^{91}$ Yet by then the light of the lantern had long ceased to be the laughter of heaven. ${ }^{92}$

87 Findlen, op. cit. (2).

88 E.g. Hooke's ‘sincere hand and faithful eye’. See also S. Alpers, op. cit. (83), Chapter 3.

89 Burke, op. cit. (69).

90 Hobson, op. cit. (15), 43.

91 In the seventeenth century Jesuit missionaries showed the lantern as a marvel, but the use of religious images started only in the nineteenth century, and even then they often wondered if it was a morally appropriate way to convert the heathen (see P. Landau, 'The illumination of Christ in the Kalahari Desert', Representations (1994), 45, 26-40). 92 See the epigraph. 